University of Nebraska - Lincoln

DigitalCommons@University of Nebraska - Lincoln

US Department of Energy Publications

U.S. Department of Energy

2011

Multiple benzene-formation paths in a fuel-rich cyclohexane flame

Wenjun Li

North Carolina State University, Raleigh, NC

Matthew Law

University of Massachusetts, Amherst, MA

Phillip Westmoreland

North Carolina State University, Raleigh, NC

Tina Kasper

Sandia National Laboratories, Livermore, CA

Nils Hansen

Sandia National Laboratories, Livermore, CA

See next page for additional authors

Follow this and additional works at: https://digitalcommons.unl.edu/usdoepub

Part of the Bioresource and Agricultural Engineering Commons

Li, Wenjun; Law, Matthew; Westmoreland, Phillip; Kasper, Tina; Hansen, Nils; and Kohse-Höinghaus, Katharina, "Multiple benzene-formation paths in a fuel-rich cyclohexane flame" (2011). US Department of Energy Publications. 122.

https://digitalcommons.unl.edu/usdoepub/122

This Article is brought to you for free and open access by the U.S. Department of Energy at DigitalCommons@University of Nebraska - Lincoln. It has been accepted for inclusion in US Department of Energy Publications by an authorized administrator of DigitalCommons@University of Nebraska - Lincoln. 


\section{Authors}

Wenjun Li, Matthew Law, Phillip Westmoreland, Tina Kasper, Nils Hansen, and Katharina Kohse-Höinghaus 


\title{
Multiple benzene-formation paths in a fuel-rich cyclohexane flame
}

\author{
Wenjun Li ${ }^{\text {a }}$, Matthew E. Law ${ }^{\text {b,c,1 }}$, Phillip R. Westmoreland ${ }^{\mathrm{a}, \mathrm{b}, *}$, Tina Kasper ${ }^{\mathrm{c}, 2}$, Nils Hansen ${ }^{\mathrm{c}, *}$, \\ Katharina Kohse-Höinghaus ${ }^{\mathrm{d}}$
}

${ }^{a}$ Department of Chemical and Biomolecular Engineering, North Carolina State University, Raleigh, NC 27695, USA

${ }^{\mathrm{b}}$ Department of Chemical Engineering, University of Massachusetts, Amherst, MA 01003, USA

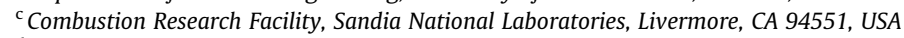

${ }^{\mathrm{d}}$ Department of Chemistry, Bielefeld University, D-33615 Bielefeld, Germany

\section{A R T I C L E I N F O}

\section{Article history:}

Received 30 November 2010

Received in revised form 28 February 2011

Accepted 25 March 2011

Available online 30 April 2011

\section{Keywords:}

Cyclohexane

Benzene

Mechanism

Oxidation

MBMS

Aromatics

\begin{abstract}
A B S T R A C T
Detailed data and modeling of cyclohexane flames establish that a mixture of pathways contributes to benzene formation and that this mixture changes with stoichiometry. Mole-fraction profiles are mapped for more than 40 species in a fuel-rich, premixed flat flame $\left(\phi=2.0\right.$, cyclohexane $/ \mathrm{O}_{2} / 30 \% \mathrm{Ar}$, $30 \mathrm{Torr}$, $50.0 \mathrm{~cm} / \mathrm{s}$ ) using molecular-beam mass spectrometry with VUV-photoionization at the Advanced Light Source of the Lawrence Berkeley National Laboratory. The use of a newly constructed set of reactions leads to an excellent simulation of this flame and an earlier stoichiometric flame (M.E. Law et al., Proc. Combust. Inst. 31 (2007) 565-573), permitting analysis of the contributing mechanistic pathways. Under stoichiometric conditions, benzene formation is found to be dominated by stepwise dehydrogenation of the six-membered ring with cyclohexadienyl $\rightleftarrows$ benzene $+\mathrm{H}$ being the final step. This finding is in accordance with recent literature. Dehydrogenation of the six-membered ring is also found to be a dominant benzene-formation route under fuel-rich conditions, at which $\mathrm{H}_{2}$ elimination from 1,3-cyclohexadiene contributes even more than cyclohexadienyl decomposition. Furthermore, at the fuel-rich condition, additional reactions make contributions, including the direct route via $2 \mathrm{C}_{3} \mathrm{H}_{3} \rightleftarrows$ benzene and more importantly the $\mathrm{H}$-assisted isomerization of fulvene formed from $i-\mid n-\mathrm{C}_{4} \mathrm{H}_{5}+\mathrm{C}_{2} \mathrm{H}_{2}, \mathrm{C}_{3} \mathrm{H}_{3}+$ allyl, and $\mathrm{C}_{3} \mathrm{H}_{3}+\mathrm{C}_{3} \mathrm{H}_{3}$. Smaller contributions towards benzene formation arise from $\mathrm{C}_{4} \mathrm{H}_{3}+\mathrm{C}_{2} \mathrm{H}_{3}, 1,3-\mathrm{C}_{4} \mathrm{H}_{6}+\mathrm{C}_{2} \mathrm{H}_{3}$, and potentially via $n-\mathrm{C}_{4} \mathrm{H}_{5}+\mathrm{C}_{2} \mathrm{H}_{2}$. This diversity of pathways is shown to result nominally from the temperature and the concentrations of benzene precursors present in the benzene-formation zone, which are ultimately due to the feed stoichiometry.
\end{abstract}

(c) 2011 The Combustion Institute. Published by Elsevier Inc. All rights reserved.

\section{Introduction}

Recent reviews by Wang [1] and Bockhorn et al. [2] emphasize that there is strong continuing practical and conceptual interest in soot-formation chemistry in combustion environments. Despite decades of combustion research, fundamental challenges remain, especially in the context of soot precursor chemistry. In this respect, a better, science-based understanding of aromatics formation and of the subsequent molecular-weight growth reactions in combustion is critically needed for further development of models for soot formation.

\footnotetext{
* Corresponding authors. Addresses: Department of Chemical and Biomolecular Engineering, North Carolina State University, Raleigh, NC 27695, USA. Fax: +1 919 5153465 (P.R. Westmoreland), Combustion Research Facility, Sandia National Laboratories, Livermore, CA 94551, USA. Fax: +1 9252942276 (N. Hansen).

E-mail addresses: phil.westmoreland@ncsu.edu (P.R. Westmoreland), nhansen@ sandia.gov (N. Hansen).

1 Present address: OFS, Somerset, NJ 08873, USA.

2 Present address: Universität Duisburg-Essen, Germany.
}

A recent comparison of benzene formation in fuel-rich flames ( $\phi=1.7)$ of isomeric cycloalkanes (cyclohexane and methylcyclopentane) and acyclic alkenes (1-hexene and 3,3-dimethyl-1-butene) revealed that fuel structure has an influence on how benzene is formed [3]. The striking differences in the mix of different benzene-formation routes observed in that work call for a better mechanistic and quantitative understanding. To this end, the present work applies new data and a newly developed chemical kinetics model to a fuel-rich $(\phi=2.0)$ cyclohexane flat flame to determine the balance of benzene-formation routes from cyclohexane at pollutant-forming conditions. Taken together with the practical importance of cycloalkanes in petroleum and petroleum-derived liquid fuels [4] and cycloalkane use in surrogate fuels [5-7], a focused analysis of the flame chemistry of cyclohexane is timely.

Cyclohexane combustion has been studied previously in a variety of experiments including flat flames with molecular-beam mass spectrometry (MBMS) [3,8], jet-stirred reactors $[9,10]$, counterflow diffusion flames [11], rapid-compression machines [12], co-flow non-premixed flames [13,14], shock tubes [15-17], 
cylinder engines [18], very-low-pressure-pyrolysis (VLPP) reactors [19], and static reactors [20]. Mechanistic models based on detailed chemistry have been proposed $[5,8,20-25]$ to explain these experimental data.

A particularly interesting feature observed for cyclohexane is that it has been shown to form benzene by sequential dehydrogenation steps of $\mathrm{H}$-abstraction from the $\mathrm{C}_{6}$-ring molecule and $\mathrm{H}$ loss from the resulting radical by $\beta$-scission [8]. This route constitutes an alternative benzene-forming path to benzene formation from small radicals like $\mathrm{C}_{3} \mathrm{H}_{3}, \mathrm{C}_{3} \mathrm{H}_{5}$, or $i-\mathrm{C}_{4} \mathrm{H}_{5}$ that is found to be typical in many flames $[3,26]$. The dehydrogenation process was proposed by Zeelenberg and Bruijn [27], and there has since been evidence for its occurrence in the combustion of cyclohexane $[3,8-$ $10,12,18,21,22]$, cyclohexene [12,14,28,29], 1,3-cyclohexadiene [12,14], 1,4-cyclohexadiene [12], and methylcyclopentane [3].

In this study, newly measured mole-fraction profiles from a fuel-rich cyclohexane flame $(\phi=2.0)$ are used in conjunction with profiles from the previously studied stoichiometric cyclohexane flame [8] to unravel the effect of stoichiometry on the importance of various benzene-formation pathways. Combined with detailed flame-chemistry modeling, the results show that stepwise dehydrogenation dominates benzene formation in both flames. In addition, small radicals like $\mathrm{C}_{3} \mathrm{H}_{3}$, allyl, and $i-\mathrm{C}_{4} \mathrm{H}_{5}$ make substantial contributions in the fuel-rich flame, which is in contrast to the stoichiometric flame. While all aromatic-ring species are considered as the possible first aromatics, benzene is shown clearly to be dominant.

\section{Experimental procedures}

A fuel-rich cyclohexane $/ \mathrm{O}_{2} / 30 \%$ Ar flame $(\phi=2.0)$ is stabilized on a water-cooled, porous stainless-steel, McKenna-type burner in a low-pressure reaction chamber at $40.0 \mathrm{mbar}$ (30.0 Torr). The cold-flow velocity of the unburned gases is $50.0 \mathrm{~cm} / \mathrm{s}$ at $298 \mathrm{~K}$ and the mass-flow rate is $3.28 \times 10^{-3} \mathrm{~g} / \mathrm{cm}^{2} / \mathrm{s}$. The gas flows are controlled with calibrated mass flow controllers, and the flow of cyclohexane is metered by a syringe pump, evaporated, and quantitatively added into the gas stream.

The apparatus and procedures used to study the chemical composition of this flame have been detailed in several previous papers [30-34]. In short, mole-fraction profiles for individual flame species are obtained by molecular-beam flame sampling using a time-of-flight mass spectrometer at the Advanced Light Source (ALS) of the Lawrence Berkeley National Laboratory. Flame species are sampled through a quartz cone with an orifice diameter of $\sim 400 \mu \mathrm{m}$. Before the sampled gases pass into the ionization region, the expanding beam is collimated by a $2.0-\mathrm{mm}$-aperture nickel skimmer placed $\sim 23 \mathrm{~mm}$ downstream of the quartz cone. The flame species are subsequently photo-ionized by synchrotron-generated vacuum-ultraviolet (VUV) photons over the energy range of 8-17 eV with a typical energy resolution of $0.05 \mathrm{eV}$ (fwhm).

Species are identified by mass-to-charge $(\mathrm{m} / \mathrm{z})$ ratios and by ionization thresholds from photon-energy scans at fixed burner locations. Burner scans are performed at fixed photon energies to measure mole-fraction profiles. The data calibration methods have been described previously [31,32,35], where details are reported. Major species are quantified by direct calibration. For example, the mole fraction of $\mathrm{C}_{2} \mathrm{H}_{2}$ is calibrated using both $\mathrm{C}_{2} \mathrm{H}_{2} / \mathrm{Ar}$ at $16.2 \mathrm{eV}$ and $\left(\mathrm{C}_{2} \mathrm{H}_{2}\right.$ at $\left.12.3 \mathrm{eV}\right) /\left(\mathrm{H}_{2} \mathrm{O}\right.$ at $\left.13.2 \mathrm{eV}\right)$. Other minor species are generally calibrated step-by-step using their photoionization cross sections, choosing intermediates with known mole fractions that have already been calibrated. The precision of the quantitative mole-fraction profiles is estimated to be within $15 \%$ for the major species (first method of Ref. [35]), 30\% for intermediates with reliably measured photoionization cross sections, and approximately a factor of two or larger for other intermediates with unknown cross sections, where cross sections are estimated from those of similar molecules or by the method of Koizumi [36]. The partial-equilibrium method, well established in flame science [37], is used to convert the photoionization MBMS data for $\mathrm{H}$ and the laser-inducedfluorescence data for $\mathrm{OH}$ into mole fractions, giving an uncertainty close to that of the major species; detailed procedures for this method are provided in the Supplemental material. Where new cross-section data are available, the stoichiometric-flame data of Law et al. [8] are updated as well.

In total, mole-fraction profiles are measured as function of distance from the burner surface for more than 40 flame species ranging from $m / z=1$ (H-atom) to $m / z=106$ (xylenes). All identified flame species are listed in Table 1 . Also listed are the photon energies used for detection of the individual species and their respective photoionization cross-section used for quantification. Individual peak mole fractions and positions are also given in $\mathrm{Ta}$ ble 1 . The full set of experimental mole-fraction data is provided in the Supplemental material.

With the intent of correcting for probe perturbation $[47,48]$ and to match axial positions of the experimentally determined molefraction profiles with the modeling results, the experimental mole-fraction profiles are shifted by $2.0 \mathrm{~mm}$ toward the burner surface.

The temperature profile is measured in a flame undisturbed by the probe cone using $\mathrm{OH}$ laser-induced fluorescence near $306 \mathrm{~nm}$, as described in Hansen et al. [49]. The burner surface temperature is assumed to be $400 \mathrm{~K}$, and a smoothed profile is used as model input. The uncertainty is estimated to be $\pm 150 \mathrm{~K}$ in the post-flame zone and possibly higher in the flame reaction zone.

The area-expansion ratio profile used in modeling is taken from Law et al. [8].

\section{Flame-chemistry modeling}

The reaction set used to model the data from the newly analyzed fuel-rich cyclohexane flame and the previously published stoichiometric flame [8] is derived from an earlier version by Law et al. [8]. Updating the previous model is necessary in order to achieve a better understanding of the fuel consumption chemistry and an accurate treatment of the small-radical chemistry. The updated model, which is provided as Supplementary material, now includes: (a) recent theoretical calculations regarding the chemistry of $\mathrm{C}_{3} \mathrm{H}_{3}, \mathrm{C}_{3} \mathrm{H}_{5}$, and $\mathrm{C}_{4} \mathrm{H}_{5}$ radicals; (b) proposed benzene-formation routes via $\mathrm{C}_{2} \mathrm{H}_{3}$ plus $\mathrm{C}_{4} \mathrm{H}_{x}$ species; (c) a better description of fuel-consumption processes through $\mathrm{H}_{2}$ elimination and isomerization; and (d) fall-off estimations using Quantum-RRK $[50,51]$ for $\mathrm{C}_{6}$-species reactions. The updates are summarized as follows:

- $\mathrm{C}_{3} \mathrm{H}_{3}+\mathrm{H} \rightleftarrows \mathrm{C}_{3} \mathrm{H}_{4}$ (allene and propyne) with falloff from Miller and Klippenstein [52].

- $\mathrm{C}_{3} \mathrm{H}_{2}$ (propargylene) $+\mathrm{H} \rightleftarrows \mathrm{C}_{3} \mathrm{H}_{3}$ by Harding et al. [53], corrected for falloff.

- $\mathrm{C}_{3} \mathrm{H}_{3}+\mathrm{C}_{3} \mathrm{H}_{3}$ by Miller and Klippenstein [54] and Hansen et al. [55].

- $\mathrm{H}+\mathrm{C}_{4} \mathrm{H}_{2}$ (diacetylene) $\rightleftarrows i$ - and $n-\mathrm{C}_{4} \mathrm{H}_{3}$ by Klippenstein and Miller [56].

- $\mathrm{C}_{2} \mathrm{H}_{3}+n-\mathrm{C}_{4} \mathrm{H}_{3} \rightleftarrows \mathrm{C}_{6} \mathrm{H}_{6}$ from Duran et al. [57].

- $\mathrm{C}_{2} \mathrm{H}_{3}+1,3$-butadiene $\rightleftarrows \mathrm{C}_{6} \mathrm{H}_{6}+\mathrm{H}_{2}+\mathrm{H}$ by Leung and Lindstedt [58].

- $i$ - and $n-\mathrm{C}_{4} \mathrm{H}_{5}+\mathrm{C}_{2} \mathrm{H}_{2} \rightleftarrows \mathrm{C}_{6} \mathrm{H}_{6}$ isomers from Senosiain and Miller [59].

- $\mathrm{C}_{3} \mathrm{H}_{3}+\mathrm{C}_{3} \mathrm{H}_{5} \rightleftarrows$ fulvene $+2 \mathrm{H}$ by Georgievskii et al. [60].

- 1,3-Butadiene $+\mathrm{O}, 1,3$-butadiene $+\mathrm{OH}$, and $i-\mathrm{C}_{4} \mathrm{H}_{5}+\mathrm{H} \rightleftarrows \mathrm{C}_{3} \mathrm{H}_{3}+$ $\mathrm{CH}_{3}$ by Hansen et al. [55]. 
Table 1

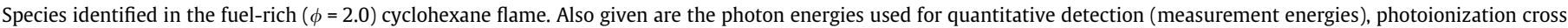
sections, and peak mole fractions $x$ and positions as functions of distance from the burner $(z)$ in the data and the simulation.

\begin{tabular}{|c|c|c|c|c|c|c|c|}
\hline Mass & Species & Measurement energy (eV) & Cross section (MB) and source & $\begin{array}{l}\text { Data } \\
x \\
\end{array}$ & $\begin{array}{l}\text { Peak } \\
z, \mathrm{~mm}\end{array}$ & $\begin{array}{l}\text { Model } \\
x\end{array}$ & $\begin{array}{l}\text { Peak } \\
z, \mathrm{~mm}\end{array}$ \\
\hline 1 & Hydrogen atom, $\mathrm{H}$ & 14.35 & $\mathrm{X}^{\mathrm{a}}$ [partial eq] & $1.4 \mathrm{E}-2$ & 9.0 & $1.2 \mathrm{E}-2$ & 8.5 \\
\hline 2 & Hydrogen, $\mathrm{H}_{2}$ & 16.20 & $X^{a}$ & $0.13^{\mathrm{b}}$ & 2.9 & $0.12^{\mathrm{b}}$ & 2.5 \\
\hline 15 & Methyl, $\mathrm{CH}_{3}$ & 11.50 & $5.4[38]$ & $3.3 \mathrm{E}-3$ & 5.0 & $6.1 \mathrm{E}-3$ & 4.5 \\
\hline 16 & Methane, $\mathrm{CH}_{4}$ & 13.20 & 5.5 [39] & $1.3 \mathrm{E}-2$ & 4.0 & $1.3 \mathrm{E}-2$ & 4.0 \\
\hline 17 & Hydroxyl, OH & 15.68 & $\mathrm{X}^{\mathrm{a}}$ [partial eq] & $1.7 \mathrm{E}-3$ & 8.0 & $2.4 \mathrm{E}-3$ & 8.0 \\
\hline 18 & Water, $\mathrm{H}_{2} \mathrm{O}$ & 16.20 & $X^{a}$ & $2.1 \mathrm{E}-1$ & 8.0 & $2.2 \mathrm{E}-1$ & 8.0 \\
\hline 26 & Acetylene, $\mathrm{C}_{2} \mathrm{H}_{2}$ & 12.30 & $29.7[40]$ & $4.2 \mathrm{E}-2$ & 5.5 & $4.6 \mathrm{E}-2$ & 5.4 \\
\hline 28 & Ethylene, $\mathrm{C}_{2} \mathrm{H}_{4}$ & 11.50 & $13.5[31]$ & $2.5 \mathrm{E}-2$ & 5.0 & $4.5 \mathrm{E}-2$ & 3.8 \\
\hline 28 & $\mathrm{CO}$ & 14.35 & $\mathrm{X}^{\mathrm{a}}$ & $0.18^{\mathrm{b}}$ & 3.2 & $0.17^{\mathrm{b}}$ & 3.5 \\
\hline 29 & Ethyl, $\mathrm{C}_{2} \mathrm{H}_{5}$ & 10.00 & $13.0[41]$ & $4.6 \mathrm{E}-4$ & 4.0 & $8.7 \mathrm{E}-4$ & 3.2 \\
\hline 30 & Ethane, $\mathrm{C}_{2} \mathrm{H}_{6}$ & 12.30 & $13.2[42]$ & $1.9 \mathrm{E}-3$ & 3.5 & $1.8 \mathrm{E}-3$ & 3.0 \\
\hline 30 & Formaldehyde, $\mathrm{CH}_{2} \mathrm{O}$ & 11.50 & $10.2[43]$ & $1.6 \mathrm{E}-2$ & 2.5 & $1.3 \mathrm{E}-2$ & 3.2 \\
\hline 32 & Oxygen, $\mathrm{O}_{2}$ & 16.20 & $\mathrm{X}^{\mathrm{a}}$ & $0.22^{\mathrm{b}}$ & 3.2 & $0.24^{\mathrm{b}}$ & 2.9 \\
\hline 39 & Propargyl, $\mathrm{C}_{3} \mathrm{H}_{3}$ & 10.50 & $8.9[44]$ & $1.6 \mathrm{E}-3$ & 4.5 & $1.4 \mathrm{E}-3$ & 4.2 \\
\hline 40 & Argon, $\mathrm{Ar}$ & 16.20 & $X^{a}$ & - & - & - & - \\
\hline 40 & Allene, $\mathrm{C}_{3} \mathrm{H}_{4}$ & 10.00 & $6.6[30]$ & $4.0 \mathrm{E}-4$ & 3.5 & $9.1 \mathrm{E}-4$ & 3.9 \\
\hline 40 & Propyne, $\mathrm{C}_{3} \mathrm{H}_{4}$ & 11.50 & $42.1[30]$ & 8.7E-4 & 4.0 & $1.0 \mathrm{E}-3$ & 3.9 \\
\hline 41 & Allyl, $\mathrm{C}_{3} \mathrm{H}_{5}$ & 10.50 & $6.1[45]$ & $8.1 \mathrm{E}-4$ & 3.0 & $9.8 \mathrm{E}-4$ & 3.9 \\
\hline 42 & Propene, $\mathrm{C}_{3} \mathrm{H}_{6}{ }^{\mathrm{d}}$ & 11.50 & $13.1[31]$ & $2.9 \mathrm{E}-3$ & 3.5 & $2.6 \mathrm{E}-3$ & 3.6 \\
\hline 42 & Ketene, $\mathrm{CH}_{2} \mathrm{CO}^{\mathrm{d}}$ & 9.69 & $6.9^{\mathrm{e}}$ & $2.6 \mathrm{E}-3$ & 4.5 & $2.8 \mathrm{E}-3$ & 3.8 \\
\hline 43 & Formylmethyl, $\mathrm{CH}_{2} \mathrm{CHO}$ & 11.50 & 8.3, $\mathrm{Est}^{\mathrm{C}}$ & 4.3E-4 & 4.0 & $2.7 \mathrm{E}-5$ & 3.9 \\
\hline 44 & $\mathrm{CO}_{2}$ & 14.35 & $X^{a}$ & $2.7 \mathrm{E}-2^{\mathrm{b}}$ & 4.3 & $2.7 \mathrm{E}-2^{\mathrm{b}}$ & 4.5 \\
\hline 50 & Diacetylene, $\mathrm{C}_{4} \mathrm{H}_{2}$ & 11.50 & $33.8[40]$ & $2.6 \mathrm{E}-3$ & 5.0 & $4.4 \mathrm{E}-3$ & 5.3 \\
\hline 52 & Vinyl acetylene, $\mathrm{C}_{4} \mathrm{H}_{4}$ & 10.50 & $33.2[40]$ & $1.2 \mathrm{E}-3$ & 4.0 & $1.3 \mathrm{E}-3$ & 3.9 \\
\hline 53 & $\mathrm{C}_{4} \mathrm{H}_{5}{ }^{\mathrm{f}}$ & 9.69 & 6.7, $\mathrm{Est}^{\mathrm{c}}$ & $6.5 \mathrm{E}-4$ & 4.0 & $6.5 \mathrm{E}-4$ & 3.8 \\
\hline 54 & 1,3-Butadiene, $\mathrm{C}_{4} \mathrm{H}_{6}$ & 10.00 & $14.9^{\mathrm{e}}$ & $1.3 \mathrm{E}-2$ & 3.0 & $1.5 \mathrm{E}-2$ & 3.0 \\
\hline 55 & $\mathrm{C}_{4} \mathrm{H}_{7}{ }^{\mathrm{f}}$ & 9.69 & $6.8 \mathrm{Est}^{\mathrm{c}}$ & $3.6 \mathrm{E}-4$ & 3.5 & $1.6 \mathrm{E}-4$ & 3.5 \\
\hline 56 & 2-Butene, $\mathrm{C}_{4} \mathrm{H}_{8}$ & 9.40 & $5.9^{\mathrm{e}, \mathrm{g}}$ & $3.0 \mathrm{E}-4$ & 3.0 & $\mathrm{X}^{\mathrm{a}}$ & $\mathrm{X}^{\mathrm{a}}$ \\
\hline 56 & 1-Butene, $\mathrm{C}_{4} \mathrm{H}_{8}$ & 10.00 & $9.4[42]$ & $3.6 \mathrm{E}-4$ & 3.0 & $3.7 \mathrm{E}-4$ & 2.9 \\
\hline 65 & Cyclopentadienyl, $\mathrm{C}_{5} \mathrm{H}_{5}$ & 9.69 & $X^{a}$ & $\mathrm{X}^{\mathrm{a}}$ & $X^{a}$ & $6.9 \mathrm{E}-5$ & 4.6 \\
\hline 66 & cyclopentadiene, $\mathrm{C}_{5} \mathrm{H}_{6}$ & 10.50 & 20.0, $\mathrm{Est}^{\mathrm{C}}$ & $6.1 \mathrm{E}-4$ & 3.5 & $8.6 \mathrm{E}-5$ & 3.2 \\
\hline 67 & $\mathrm{C}_{5} \mathrm{H}_{7}{ }^{\mathrm{f}}$ & 10.00 & 7.6, $\mathrm{Est}^{\mathrm{C}}$ & $1.3 \mathrm{E}-4$ & 4.5 & $X^{a}$ & $X^{a}$ \\
\hline 68 & 1,3-Pentadiene, $\mathrm{C}_{5} \mathrm{H}_{8}$ & 9.00 & $6.6^{\mathrm{e}}$ & $1.4 \mathrm{E}-3$ & 4.0 & $\mathrm{X}^{\mathrm{a}}$ & $\mathrm{X}^{\mathrm{a}}$ \\
\hline 68 & Cyclopentene, $\mathrm{C}_{5} \mathrm{H}_{8}$ & 10.50 & $12.6^{\mathrm{e}}$ & $3.3 \mathrm{E}-4$ & 4.0 & $\mathrm{X}^{\mathrm{a}}$ & $\mathrm{X}^{\mathrm{a}}$ \\
\hline 70 & 2-Pentene, $\mathrm{C}_{5} \mathrm{H}_{10}$ & 9.69 & $14.2[30]^{\mathrm{e}}$ & $7.9 \mathrm{E}-4$ & 3.5 & $\mathrm{X}^{\mathrm{a}}$ & $\mathrm{X}^{\mathrm{a}}$ \\
\hline 74 & 1,3,5-Hexatriyne, $\mathrm{C}_{6} \mathrm{H}_{2}$ & 10.50 & 7.9, Est $^{\mathrm{c}}$ & $6.0 \mathrm{E}-4$ & 4.5 & $2.8 \mathrm{E}-4$ & 5.9 \\
\hline 76 & Benzyne, $\mathrm{C}_{6} \mathrm{H}_{4}$ & 10.00 & 7.9, Est $^{\mathrm{c}}$ & $1.0 \mathrm{E}-4$ & 5.0 & $5.0 \mathrm{E}-5$ & 5.7 \\
\hline 78 & Fulvene, $\mathrm{C}_{6} \mathrm{H}_{6}$ & 9.09 & 10.0, $\mathrm{Est}^{\mathrm{c}}$ & $4.0 \mathrm{E}-5$ & 4.5 & 4.3E-5 & 3.3 \\
\hline 78 & Benzene, $\mathrm{C}_{6} \mathrm{H}_{6}$ & 10.00 & $24.3[31]$ & $5.1 \mathrm{E}-4$ & 3.5 & $5.5 \mathrm{E}-4$ & 3.9 \\
\hline 80 & 1,3-Cyclohexadiene, $\mathrm{C}_{6} \mathrm{H}_{8}$ & 10.00 & $22.5[42]$ & $7.8 \mathrm{E}-4$ & 3.0 & $1.2 \mathrm{E}-4$ & 3.3 \\
\hline 82 & Cyclohexene, $c-\mathrm{C}_{6} \mathrm{H}_{10}$ & 10.00 & $11.6[42]$ & $9.9 \mathrm{E}-4$ & 2.5 & $5.9 \mathrm{E}-4$ & 1.9 \\
\hline 84 & Cyclohexane, $\mathrm{C}_{6} \mathrm{H}_{12}$ & 16.20 & $\mathrm{X}^{\mathrm{a}}$ & $0.061^{\mathrm{b}}$ & 2.7 & $0.061^{\mathrm{b}}$ & 2.6 \\
\hline 92 & Toluene, $\mathrm{C}_{7} \mathrm{H}_{8}$ & 9.69 & $22.3[40]$ & $2.7 \mathrm{E}-4$ & 5.0 & $2.7 \mathrm{E}-5$ & 3.8 \\
\hline 94 & 4-Methylene-cyclohexene, $\mathrm{C}_{7} \mathrm{H}_{10}$ & 9.69 & 8.6, $\mathrm{Est}^{\mathrm{c}}$ & $4.7 \mathrm{E}-4$ & 4.5 & $\mathrm{X}^{\mathrm{a}}$ & $x^{a}$ \\
\hline 96 & 3-Methylcyclohexene, $\mathrm{C}_{7} \mathrm{H}_{12}$ & 9.69 & 8.1, $\mathrm{Est}^{\mathrm{c}}$ & $2.4 \mathrm{E}-4$ & 3.5 & $\mathrm{X}^{\mathrm{a}}$ & $\mathrm{X}^{\mathrm{a}}$ \\
\hline 98 & 1,3,5,7-Octatetrayne, $\mathrm{C}_{8} \mathrm{H}_{2}$ & 9.69 & 8.4, Est ${ }^{\mathrm{C}}$ & $4.4 \mathrm{E}-4$ & 3.5 & $\mathrm{X}^{\mathrm{a}}$ & $X^{a}$ \\
\hline 102 & Phenylacetylene, $\mathrm{C}_{8} \mathrm{H}_{6}$ & 9.69 & $44.6[46]$ & $1.2 \mathrm{E}-4$ & 5.5 & 4.9E-6 & 4.5 \\
\hline 104 & Styrene, $\mathrm{C}_{8} \mathrm{H}_{8}$ & 9.69 & $30.6[46]$ & $9.2 \mathrm{E}-5$ & 5.0 & $2.2 \mathrm{E}-5$ & 3.8 \\
\hline 106 & Xylenes, $\mathrm{C}_{8} \mathrm{H}_{10}$ & 9.69 & $20.0[46]^{\mathrm{e}}$ & $8.2 \mathrm{E}-5$ & 4.5 & $\mathrm{X}^{\mathrm{a}}$ & $X^{a}$ \\
\hline
\end{tabular}

a " $\mathrm{X}$ " in the table indicates that photoionization cross sections are not used for the mole fraction determination, or that experimental or modeled mole-fraction profiles are not available.

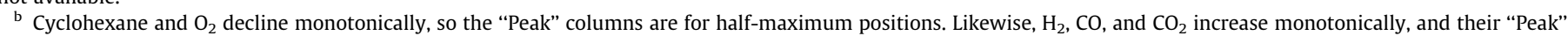
columns are for half-maximum positions.

c "Est" in the table indicates that the cross-section data is estimated by Kozumi's method [36].

d Ketene and propene have very close ionization energies ( 9.617 and $9.73 \mathrm{eV}$ ), so the two experimental profiles may have some overlap. Note that ketene is predicted to be a factor of three higher than propene.

e B. Yang, T.A. Cool, unpublished cross-section data, private communication.

f Species not identified unambiguously due to isomers with similar ionization energies.

g Cross sections are for the trans-isomers, assuming cis- and trans-isomers have similar cross sections.

- $\mathrm{H}_{2}$ elimination from 1,3-cyclohexadiene by Shandross et al. [61] and from cyclohexene by Dayma et al. [29], corrected for falloff.

- Cyclohexane $\rightleftarrows 1$-hexene isomerization and 1-hexene decomposition by Kiefer et al. [17].

- 1-Hexene model estimated by Yahyaoui et al. [62].

- 5-Hexenyl $\rightleftarrows 2$-hexenyl isomerization and ethyl +1,3-butadiene $\rightleftarrows 2$-hexenyl by Silke et al. [25], corrected for falloff.

- Fall-off corrections for decompositions of cyclohexyl, hex-5enyl, cyclohexene, cyclohex-2-enyl, and 3,5-hexadienyl.
It is important to note that these changes to the previously used model do not affect the overall conclusion for the stoichiometric flame as presented in Ref. [8]. However, as will be shown in Section 5, the updates are important for an accurate description of the flame chemistry at the fuel-rich conditions. The present model includes 121 species and 1017 reactions.

The flame-chemistry modeling, including multi-component diffusion and thermal diffusion, is performed with the CHEMKIN-II PREMIX [63-65] flame code, and XSenkplot [66] is used to 
post-process the modeling results. The XSenkplot code is adapted to give absolute reaction rates (rather than rates divided by density, in the original code), and reaction fluxes are computed by integrating with respect to distance (rather than with respect to time, which was used in the original code).

\section{General model performance}

In this section, we compare the experimentally determined mole-fraction profiles with the modeled mole-fraction profiles and discuss the quality and the predictive capability of the updated combustion chemistry model. First, results are shown for the newly analyzed fuel-rich flame (Sections 4.1-4.3). Second, mole-fraction profiles of the previously studied [8] stoichiometric cyclohexane flame are compared with the latest model predictions (Section 4.4). We will show that the agreement between model and data is generally quite good based on peak magnitude, position, and shape. Shape is particularly useful for comparing species that have significant calibration uncertainties; e.g., the model might appear to be in disagreement, but if shape and position are in agreement within calibration uncertainty, agreement is considered good. Likewise, modeling the data with different temperature profiles shows that uncertainty in temperature magnitude can shift the profile position axially, yet the shape is little affected [67].

Points at less than $1 \mathrm{~mm}$ from the burner are measurable, but those data are too distorted for valid comparison to model results. Having the probe very close to the burner quenches flame chemistry and temperatures. Furthermore, feed-gas flow through sintered metal is not one-dimensional at the surface plane, as flow is only through interstices between the sintered-metal particles in the burner surface. Thus, some distance is required for mixing. In the stoichiometric cyclohexane flame of Ref. [8], data points beginning from the surface had been reported in the Supplementary data, but we now judge that the samples from within $1 \mathrm{~mm}$ are in a region unsuitable for comparison to predictions.

In the following discussions, specific percentage values and rates are given, but numbers can change under different conditions and/or when more reliable rate constants become available. The analyses here show that the central finding holds: that multiple channels to aromatics can occur in the same flame. Specific numbers are presented to be helpful for understanding the general relative contribution from different reactions.

\subsection{Major species, temperature, $\mathrm{H}, \mathrm{O}$, and $\mathrm{OH}$ profiles}

Mole-fraction profiles of the major species $\left(\mathrm{H}_{2}, \mathrm{H}_{2} \mathrm{O}, \mathrm{CO}, \mathrm{O}_{2}, \mathrm{Ar}\right.$, $\mathrm{CO}_{2}$, and cyclohexane) are shown in Fig. 1, together with the measured temperature profile as it is used in the model calculations. Modeling results for all major species agree quite well with their respective experimental data for all burner-to-cone distances extending to $30 \mathrm{~mm}$ from the burner surface. Following the $\mathrm{Ar}$ mole-fraction profile from the burner surface, Ar initially decreases due to dilution by generation of intermediates and their back-diffusion, gradually becoming steady further away from the burner. Cyclohexane is substantially consumed by $5 \mathrm{~mm}$, with the present model slightly overpredicting the rate of the cyclohexane decay. However, measurement uncertainties cannot be ruled out, either. Large amounts of $\mathrm{CO}$ and $\mathrm{H}_{2}$ are formed, with mole fractions of $x(\mathrm{CO}) \approx 0.36$ and $x\left(\mathrm{H}_{2}\right) \approx 0.25$ at $30 \mathrm{~mm}$ away from the burner, because of the fuel-rich conditions. The slight peak in the mole-fraction profile of $\mathrm{H}_{2} \mathrm{O}$ near $7 \mathrm{~mm}$ is predicted accurately.

$\mathrm{H}$-atom, $\mathrm{O}$-atom, and $\mathrm{OH}$ are usually the most active radicals in combustion processes. Therefore, a comparison between their modeled and experimentally determined mole-fraction profiles, which is shown in Fig. 2, provides a quality test of the combustion

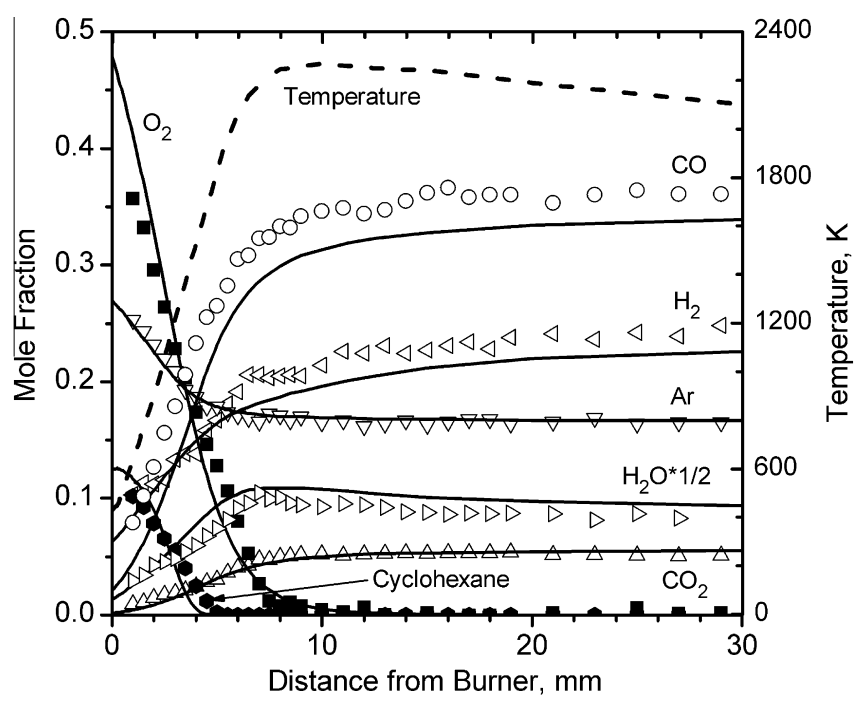

Fig. 1. Measured temperature profile, as used in the model calculation, and experimental (symbols) and modeled (lines) mole-fraction profiles of $\mathrm{H}_{2}, \mathrm{H}_{2} \mathrm{O}, \mathrm{CO}$, $\mathrm{O}_{2}, \mathrm{Ar}, \mathrm{CO}_{2}$, and cyclohexane in the fuel-rich $\phi=2.0$ cyclohexane $/ \mathrm{O}_{2} / \mathrm{Ar}$ flame.

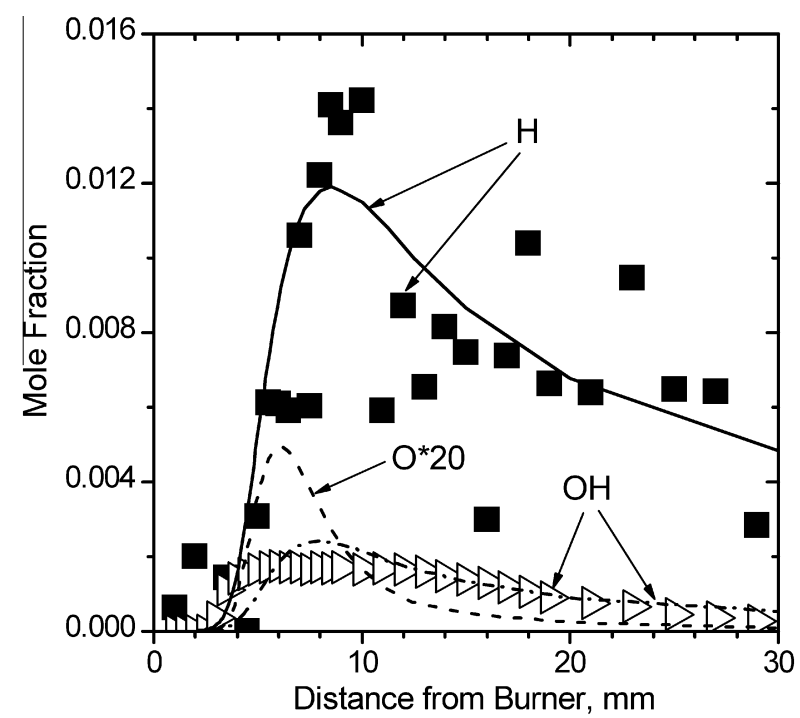

Fig. 2. Experimental (symbols) and modeled (lines) mole-fraction profiles of $\mathrm{H}, \mathrm{O}$ and $\mathrm{OH}$ as function of distance from the burner in the fuel-rich $\phi=2.0$ cyclohexane/ $\mathrm{O}_{2} / \mathrm{Ar}$ flame. Predicted $\mathrm{O}$ is multiplied by 20 to allow visual comparison.

chemistry model. It is important to note, that the experimental mole-fraction profile of the $\mathrm{H}$-atom, which unfortunately is rather noisy, is predicted successfully with our current model. Experimental and modeled mole-fraction profiles of $\mathrm{OH}$ also agree quite well, with the modeling results peaking slightly later. An O-atom profile has not been measured in this study due to its low concentration in the fuel-rich condition and because any small O-atom signal is obscured by signal from $\mathrm{CH}_{4}$.

\subsection{Benzene, fulvene, and their precursors}

The modeled fulvene and benzene mole-fraction profiles are compared with the experimentally determined profiles of these $\mathrm{C}_{6} \mathrm{H}_{6}$ isomers in Fig. 3. For benzene, the shape and position of the modeled mole-fraction profile agree well with the experimental data. The modeled fulvene mole-fraction profile appears to be somewhat narrower than experimentally determined, although 


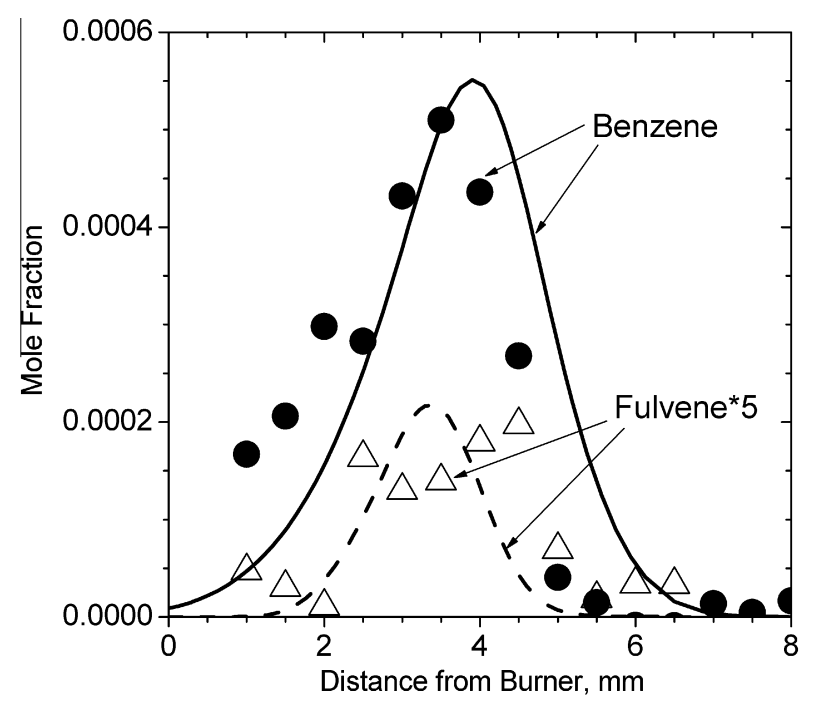

Fig. 3. Experimental (symbols) and modeled (lines) mole-fraction profiles of benzene and fulvene in the fuel-rich $\phi=2.0$ cyclohexane $/ \mathrm{O}_{2} / \mathrm{Ar}$ flame. Experimental and modeled mole fractions of fulvene are multiplied by 5 to aid visual comparison.

the profile magnitude matches well. It needs to be pointed out that a large uncertainty is associated with the experimental magnitude of fulvene because its photoionization cross section has yet to be determined.

A comparison of the observed benzene and fulvene mole-fraction profiles for the fuel-rich flame and the stoichiometric flame (shown later) reveals that the two flames have experimentally determined benzene mole-fraction profiles with close magnitudes $\left(x=5.1 \times 10^{-4}\right.$ at $3.4 \mathrm{~mm}$ and $2.7 \times 10^{-4}$ at $1.3 \mathrm{~mm}$ for the fuelrich and stoichiometric flame, respectively. The peak benzene in the stoichiometric flame is slightly smaller than Law et al. [8] following re-analysis of the original data). The fuel-rich flame has a fulvene level about 20 times higher than that in the stoichiometric flame $\left(x=3.9 \times 10^{-5}\right.$ at $4.2 \mathrm{~mm}$ and $2.3 \times 10^{-6}$ at $\left.1.2 \mathrm{~mm}\right)$; the fulvene mole fraction in the stoichiometric flame is almost below the detection limit of $\sim 1 \mathrm{ppm}$.
$\mathrm{C}_{3} \mathrm{H}_{x}(x=4-6)$ species, which are all interrelated by $\mathrm{H}$ additions and abstractions, can eventually lead to $\mathrm{C}_{3} \mathrm{H}_{3}$ (propargyl), a key precursor for aromatics in many flames [26,34,68,69]. Experimental and modeled mole-fraction profiles are shown for $\mathrm{C}_{3} \mathrm{H}_{3}, \mathrm{C}_{3} \mathrm{H}_{4}$ (allene and propyne), and $\mathrm{C}_{3} \mathrm{H}_{5}$ (allyl) in Fig. 4. For these species, a generally good agreement between experimental and model results is observed in respect to shapes, magnitudes, and positions.

$\mathrm{C}_{4} \mathrm{H}_{x}(x=3,5$, and 6$)$ species are also possible benzene precursors, given the routes proposed for $\mathrm{C}_{4} \mathrm{H}_{3}, \mathrm{C}_{4} \mathrm{H}_{5}$, and $1,3-\mathrm{C}_{4} \mathrm{H}_{6}$ $[26,58,69,70]$. Like the $\mathrm{C}_{3} \mathrm{H}_{x}$ species, the $\mathrm{C}_{4} \mathrm{H}_{x}$ species are interrelated by $\mathrm{H}$ additions and abstractions. As shown in Fig. 5a, modeled mole-fraction profiles of the molecular species $\mathrm{C}_{4} \mathrm{H}_{4}$ and $\mathrm{C}_{4} \mathrm{H}_{6}$, identified as vinylacetylene and 1,3-butadiene, respectively, have the same shapes and peak positions as the experimental data; the predicted maximum mole fractions of those two species agree with the experimental data within the expected uncertainties; see also Table 1 for a comparison. Concerning the $C_{4}$ radical species, the concentration of $\mathrm{C}_{4} \mathrm{H}_{3}$ in the fuel-rich cyclohexane flame is below the detection limit of the mass spectrometer. This small concentration of $\mathrm{C}_{4} \mathrm{H}_{3}$ might indicate that $\mathrm{C}_{4} \mathrm{H}_{3}$ is not an effective benzene precursor. For $\mathrm{C}_{4} \mathrm{H}_{5}$, the experimental data are noisy, but at about $4 \mathrm{~mm}$ above the burner surface, a definite peak, corresponding to a mole fraction of the order of $2-6.5 \times 10^{-4}$ is detectable; see Fig. 5b. At this same location, the predicted sum of all $\mathrm{C}_{4} \mathrm{H}_{5}$ mole fractions is peaking, and its magnitude is in good agreement with the experimental data, considering that the cross section is unknown. In the present study, the isomers of $\mathrm{C}_{4} \mathrm{H}_{5}$ are not resolved experimentally, but in previous work [71], Hansen et al. studied the isomeric composition of $\mathrm{C}_{4} \mathrm{H}_{5}$ radicals in rich flames fueled by allene, propyne, cyclopentene, and benzene. The thermodynamically most stable isomer $i-\mathrm{C}_{4} \mathrm{H}_{5}$ was detected, as well as one or both methyl-substituted propargyl analogs $\left(\mathrm{CH}_{3} \mathrm{CHCCH}\right.$ and $\left.\mathrm{CH}_{3} \mathrm{CCCH}_{2}\right)$. The $n-\mathrm{C}_{4} \mathrm{H}_{5}$ isomer was not detected in the study reported in Ref. [71], most likely because of the low concentration of $n-\mathrm{C}_{4} \mathrm{H}_{5}$ implied by thermochemistry and in part because of the photoionization technique's predicted low sensitivity towards this isomer. According to the present modeling results for the fuel-rich cyclohexane flame studied here, the predicted mole fractions at $3.7 \mathrm{~mm}$ above the burner surface (where the peak $\mathrm{C}_{4} \mathrm{H}_{5}$ occurs) are $6.2 \times 10^{-4}$ for $i-\mathrm{C}_{4} \mathrm{H}_{5}$ and $2.9 \times 10^{-5}$ for $n-\mathrm{C}_{4} \mathrm{H}_{5}$.
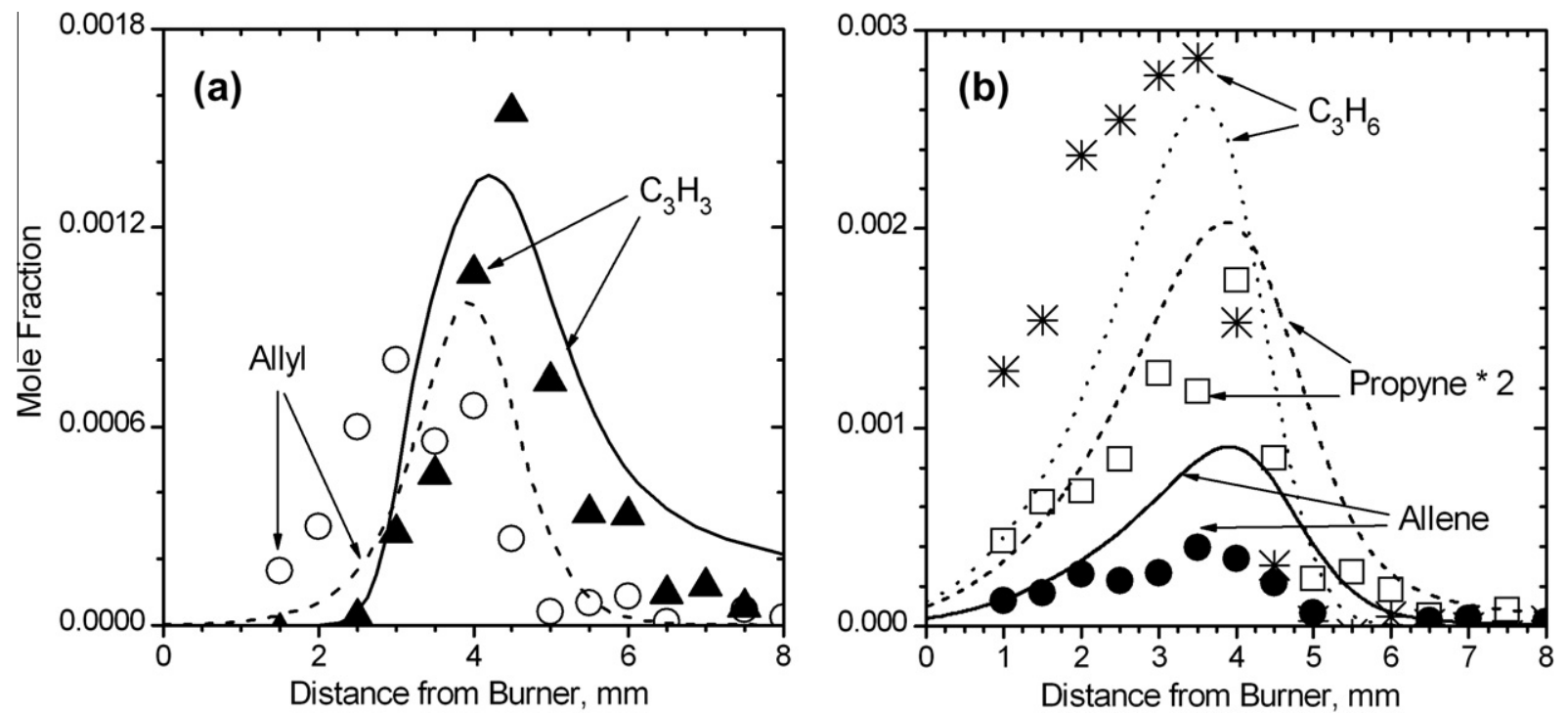

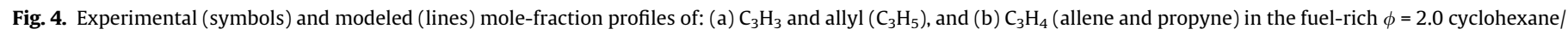
$\mathrm{O}_{2} / \mathrm{Ar}$ flame. Experimental and modeled mole-fraction profiles of propyne are multiplied by 2 . 

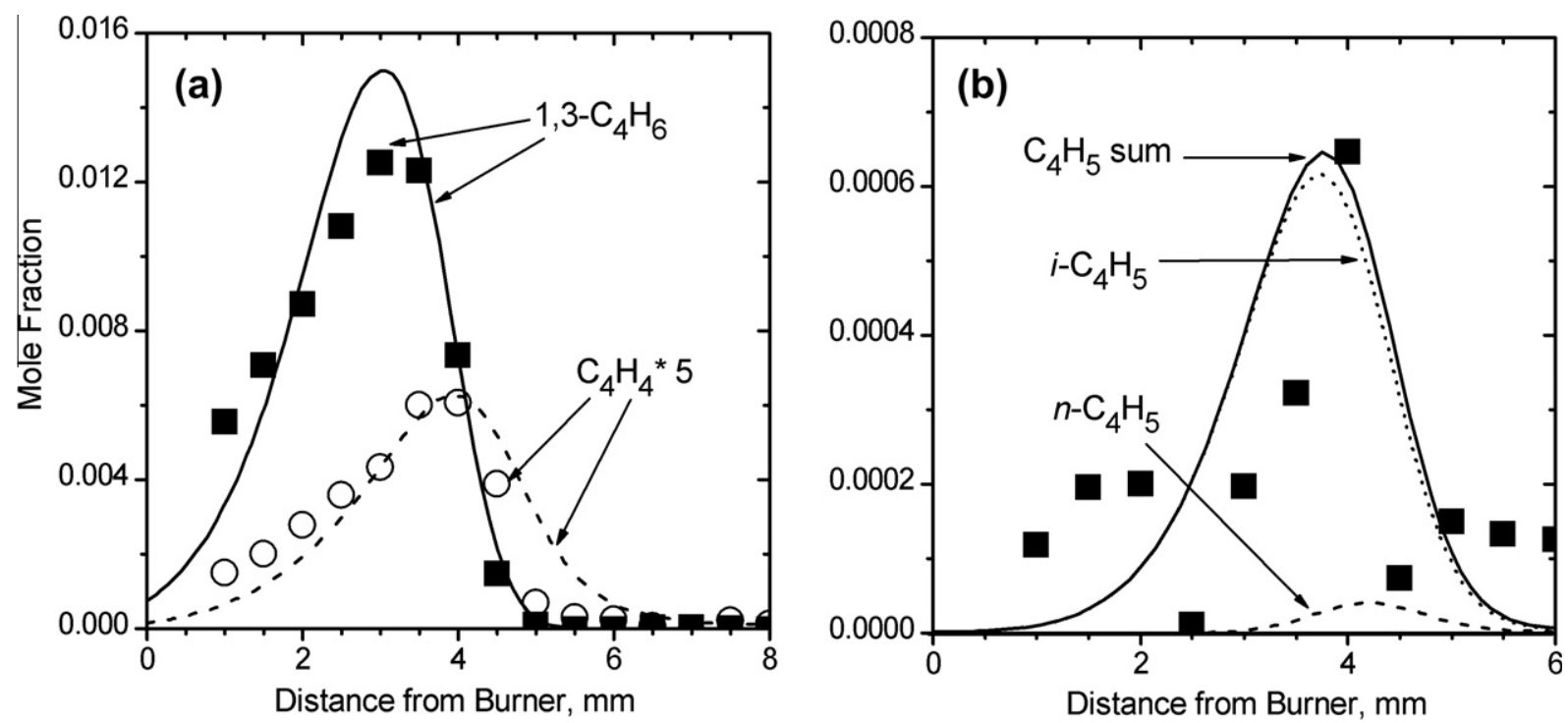

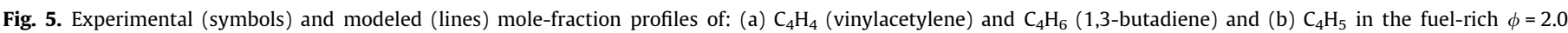

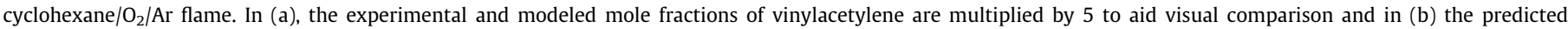
individual contributions of $i-\mathrm{C}_{4} \mathrm{H}_{5}$ (dotted line) and $n-\mathrm{C}_{4} \mathrm{H}_{5}$ (dashed line) are shown together with the sum of all $\mathrm{C}_{4} \mathrm{H}_{5}$ isomers.

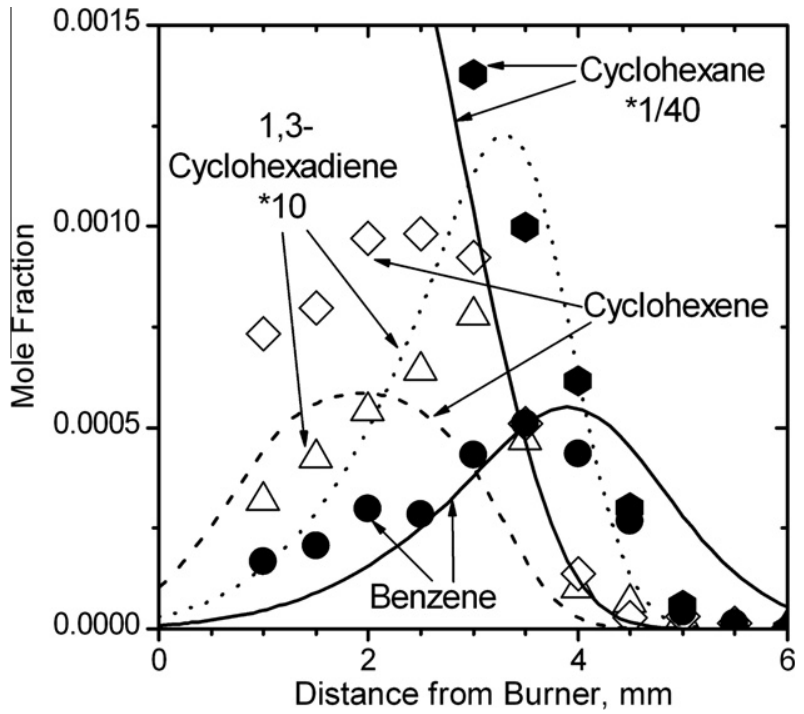

Fig. 6. Experimental (symbols) and modeled (lines) mole-fraction profiles of cyclic $\mathrm{C}_{6}$ compounds relevant for stepwise dehydrogenation in the fuel-rich $\phi=2.0$ cyclohexane $/ \mathrm{O}_{2} / \mathrm{Ar}$ flame. Experimental and modeled mole fractions of cyclohexane are scaled down by a factor of $1 / 40$ and the mole fractions of 1,3-cyclohexadiene are scaled up by a factor of 10 for ease of visual comparison.

For assessing the role of stepwise dehydrogenation in benzene formation processes, the mole-fraction profiles of cyclohexene and cyclohexadiene are valuable as well. As can be seen in Fig. 6, the model is capable of predicting their shapes, positions, and magnitudes reasonably well. Giving further insight, the dominant isomer experimentally observed at $m / z=80 \quad\left(\mathrm{C}_{6} \mathrm{H}_{8}\right)$ is 1,3cyclohexadiene rather than 1,4-cyclohexadiene.

The possibility of a benzene-formation route through $\mathrm{CH}_{3}+\mathrm{C}_{5} \mathrm{H}_{5}$ (cyclopentadienyl) has theoretical and experimental support $[3,26,72-75]$. In this flame, the $\mathrm{C}_{5} \mathrm{H}_{5}$ signal is obscured by background signal. However, $\mathrm{C}_{5} \mathrm{H}_{6}$ (cyclopentadiene) is detected only at low levels (maximum mole fraction of $6 \times 10^{-4}$ ), implying even smaller mole fractions for $\mathrm{C}_{5} \mathrm{H}_{5}$. Based on the observed low concentrations of $\mathrm{C}_{5} \mathrm{H}_{5}$ and $\mathrm{C}_{5} \mathrm{H}_{6}$, we conclude that cyclopentadienyl is not an important benzene precursor in the cyclohexane flame studied here.

\subsection{Other species}

Mole-fraction profiles for several small hydrocarbons and oxidation intermediates are presented in Fig. 7. As can be seen, the experimentally derived profiles are reproduced well by the model calculations. This observation further supports the reaction set's predictive capability and provides additional insight into fuel destruction and generation of benzene and its precursors.

For methyl and methane (Fig. 7a), the agreement between experiment and model results is good, although the peak shape indicates that their predicted consumption is not as fast as experimentally observed. The combustion chemistry model is capable of predicting profiles for formaldehyde and ketene accurately (Fig. 7b). Finally, experimental and modeled profile shapes and positions compare favorably also for acetylene (Fig. 7c), ethyl, and ethane (Fig. 7d), while ethylene is overpredicted by about $60 \%$ and diacetylene by about $50 \%$, possibly due to over-fast decomposition of the $\mathrm{C}_{6} \mathrm{H}_{11}$ isomers that are initial intermediates of fuel oxidation. Vinyl radicals are not detected because of signal interferences; however, the vinyl peak mole fraction is predicted to be $2.6 \times 10^{-4}$ at $4.2 \mathrm{~mm}$ above the burner surface.

For both $\mathrm{C}_{2} \mathrm{H}_{4}$ and $\mathrm{C}_{4} \mathrm{H}_{7}$, kinetically linked via $\mathrm{C}_{4} \mathrm{H}_{7} \rightleftarrows$ $\mathrm{C}_{2} \mathrm{H}_{3}+\mathrm{C}_{2} \mathrm{H}_{4}$, the predicted mole fractions peak nearer the burner than the experimental data. The peak-location difference could be due to ethylene formation being too fast in the model as a result of uncertainty in kinetics and/or temperatures near the burner. In the model, $\mathrm{C}_{2} \mathrm{H}_{4}$ was mainly produced from cyclohexyl $\rightleftarrows$ $\mathrm{C}_{2} \mathrm{H}_{4}+\mathrm{C}_{4} \mathrm{H}_{7}$, hex-5-en-1-yl $\rightleftarrows \mathrm{C}_{2} \mathrm{H}_{4}+\mathrm{C}_{4} \mathrm{H}_{7}, \mathrm{H}+1,3-\mathrm{C}_{4} \mathrm{H}_{6} \rightleftarrows \mathrm{C}_{2} \mathrm{H}_{3}+$ $\mathrm{C}_{2} \mathrm{H}_{4}, \mathrm{C}_{4} \mathrm{H}_{7} \rightleftarrows \mathrm{C}_{2} \mathrm{H}_{3}+\mathrm{C}_{2} \mathrm{H}_{4}$, and $\mathrm{C}_{2} \mathrm{H}_{5}$ dehydrogenation. Experimental uncertainty about the sampling shift cannot be ruled out as an explanation, although it must be applied to all species profiles.

\subsection{Stoichiometric flame}

For checking consistency, the model's predictive capabilities are also tested by modeling the stoichiometric-flame data of Law et al. [8]. A comparison for experimental and modeled mole-fraction profiles of all major species $\left(\mathrm{H}_{2}, \mathrm{H}_{2} \mathrm{O}, \mathrm{CO}, \mathrm{O}_{2}, \mathrm{Ar}, \mathrm{CO}_{2}\right.$, cyclohexane) is shown in Fig. 8. For this flame, all experimental mole-fraction profiles are shifted $1.6 \mathrm{~mm}$ towards the burner to account for probe perturbation. After this shift is applied, these predictions 

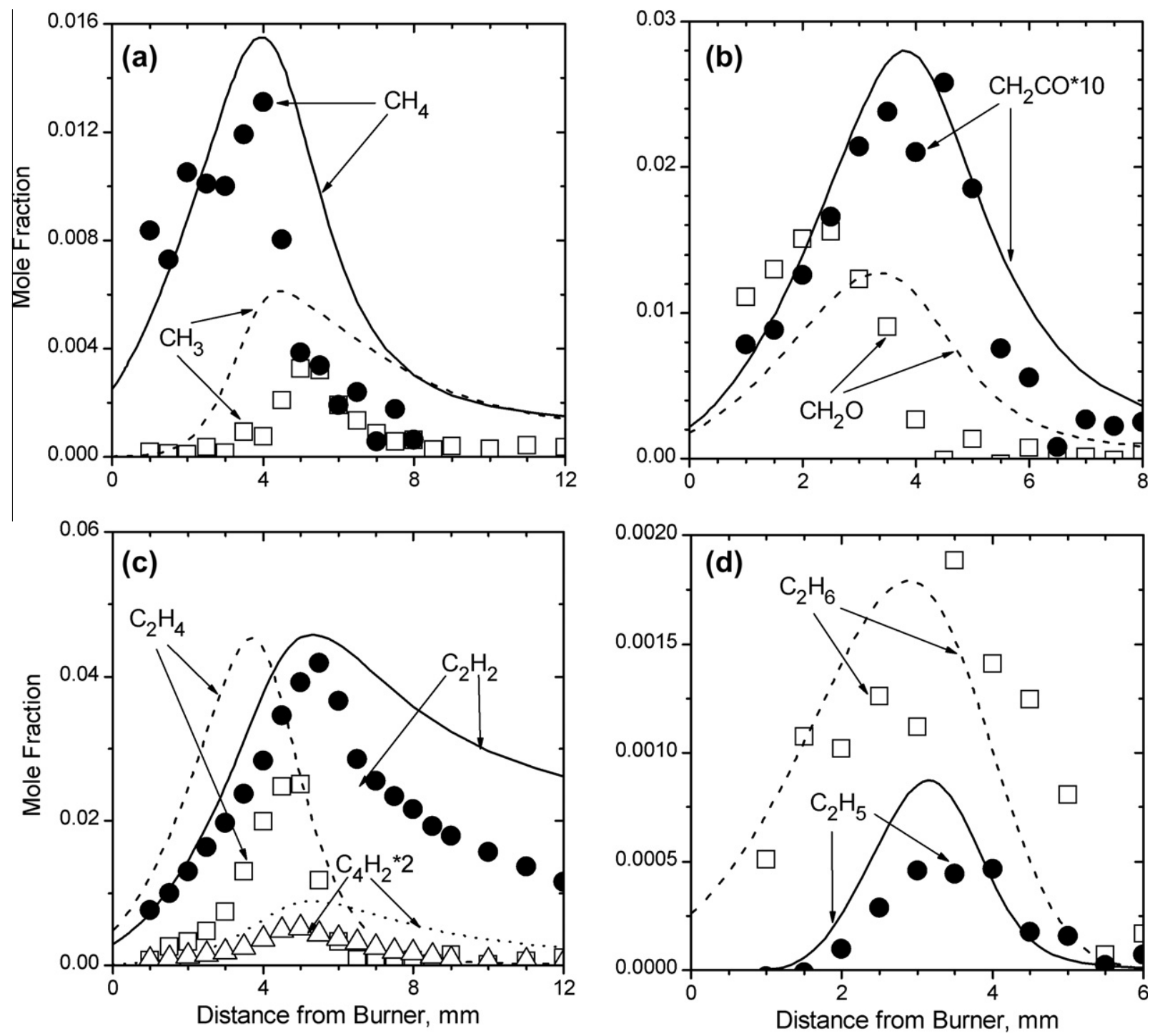

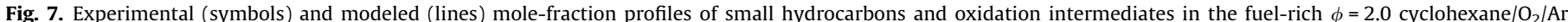

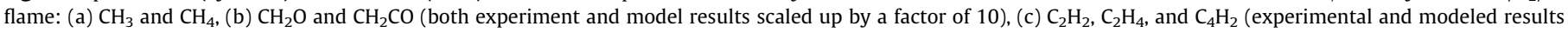
scaled up by a factor of 2 ), and (d) $\mathrm{C}_{2} \mathrm{H}_{5}$ and $\mathrm{C}_{2} \mathrm{H}_{6}$.

agree extremely well in magnitude, shape, and position with the experimental results. Even subtle data features are predicted like the slight peak in the $\mathrm{H}_{2} \mathrm{O}$ profile and the pronounced peaks of the $\mathrm{H}_{2}$ and $\mathrm{CO}$ mole-fraction profiles near $2 \mathrm{~mm}$ above the burner surface.

The comparison between experiment and model results is also reasonable for many other species in this flame, considering both the model and experimental uncertainties. For example, mole-fraction profiles are shown in Fig. 9 for cyclic $\mathrm{C}_{6} \mathrm{H}_{x}(x=6,8,10,12)$ species relevant to the stepwise dehydrogenation process and the commonly considered small-radical benzene precursors $\left(\mathrm{C}_{3} \mathrm{H}_{3}\right.$, allyl, and $\mathrm{C}_{4} \mathrm{H}_{5}$ ). The mole-fraction profile of allyl is underpredicted by $50 \%$, mole fractions of propargyl $\mathrm{C}_{3} \mathrm{H}_{3}$ are overpredicted by about $80 \%$, and mole fractions of $\mathrm{C}_{4} \mathrm{H}_{5}$ appear to be overpredicted by a factor of three; however, the general shapes and peak positions for these profiles are predicted reasonably well; see Fig. 9b. Peaks for the cyclohexene and 1,3-cyclohexadiene profiles are too close to the burner surface to be detected experimentally. However, the predicted consumption curves for these species match the experimental data quite reasonably for distances beyond $0.5 \mathrm{~mm}$ from the burner surface. The mole-fraction profile of benzene in this stoichiometric flame is predicted accurately with the current model.

Uncertainties in the model can cause the discrepancies in magnitude, but two experimental arguments can also be offered. First, the photoionization cross sections are unknown for $\mathrm{C}_{4} \mathrm{H}_{x}$ isomers. Second, the stoichiometric flame is thin, and the species profiles of most intermediates are very close to the burner surface, where probe perturbation is most significant.

Although overpredicting mole fractions of the benzene precursors $\mathrm{C}_{3} \mathrm{H}_{3}$, allyl, and $\mathrm{C}_{4} \mathrm{H}_{5}$ could cause overprediction of their contributions to benzene formation, analysis shows that these routes do not make important contributions in the stoichiometric flame.

\section{Flame chemistry insights}

The favorable agreement of the modeling results with the experimental data for so many species in the two different cyclohexane flames confirms the predictive capabilities of the reaction set proposed here. An analysis of the modeling results identifies dominant reaction pathways and also reveals sensitivities to the 


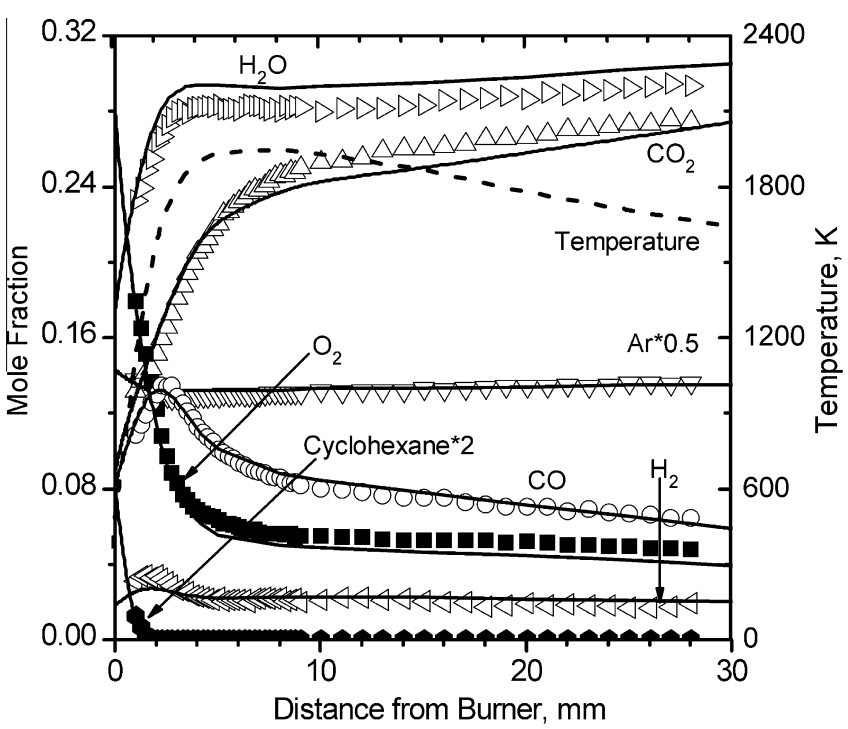

Fig. 8. Experimental (symbols) and modeled (lines) mole-fraction profiles of the major species $\left(\mathrm{H}_{2}, \mathrm{H}_{2} \mathrm{O}, \mathrm{CO}, \mathrm{O}_{2}, \mathrm{Ar}, \mathrm{CO}_{2}\right.$, cyclohexane $)$ in $\phi=1.0$ cyclohexane $/ \mathrm{O}_{2} / \mathrm{Ar}$ flame of Ref. [8]. Experimental results are shifted $1.6 \mathrm{~mm}$ towards the burner surface, and Ar is scaled down by 0.5 .

multiple reaction pathways discussed in Ref. [3] and those newly identified here.

This section is organized as follows: First, we present the reaction path analysis for benzene formation and consumption for the fuel-rich cyclohexane $/ \mathrm{O}_{2} / \mathrm{Ar}$ flame. We then compare these results with the reaction paths for benzene formation in the stoichiometric flame of Ref. [8]. Next, we discuss how the specific flame conditions (temperature, radical pool, etc.) influence the fuel consumption and the formation of the benzene precursors. Finally, we discuss the conclusions regarding the detailed chemistry of the two flames with respect to mechanistic details of the small-hydrocarbon chemistry and to the temperature profile. As will be shown, the differences on how benzene is formed in the two flames are due to the two different stoichiometries.

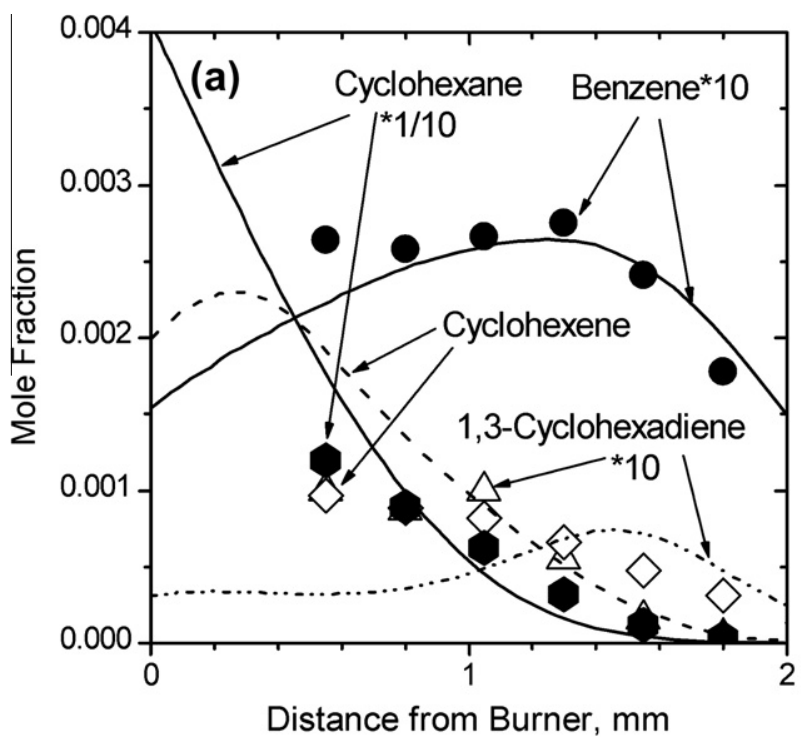

\subsection{Pathways to benzene}

Benzene and the phenyl radical are thought to be key building blocks for polycyclic aromatic hydrocarbons and soot. It is now well accepted that resonantly stabilized small radicals are critical elements of the gas-phase chemistry producing aromatic species $[26,34,68,69]$. In combustion chemistry studies, the importance of the propargyl radical is usually highlighted because its reaction with another propargyl appears to be the main source of the "first aromatic ring" in most flames burning aliphatic fuels. In some flames, benzene can also result from $\mathrm{H}$-assisted isomerization of fulvene by $\mathrm{H}+$ fulvene $\rightleftarrows \mathrm{H}+$ benzene, where fulvene is formed from $\mathrm{C}_{3} \mathrm{H}_{3}+\mathrm{C}_{3} \mathrm{H}_{3}$ [54], $\mathrm{C}_{3} \mathrm{H}_{3}+$ allyl [60,76], and/or $i-\mathrm{C}_{4} \mathrm{H}_{5}+\mathrm{C}_{2} \mathrm{H}_{2}$ $[55,59]$. Non-resonantly stabilized radicals have not been found to contribute significantly to benzene formation in combustion environments.

Multiple benzene-formation steps occur at comparable rates in the fuel-rich cyclohexane flame studied here, in contrast to the stoichiometric cyclohexane flame of Ref. [8]. It is important to note that for any comparison such as in this study, experimental and modeling uncertainties will affect the precise contributions. However, the present results provide a strong case for the structural and quantitative validity of the present data and model.

For the fuel-rich cyclohexane flame, pathways leading to and consuming benzene are summarized graphically in Fig. 10a. The figure shows reaction-specific molar rates of benzene formation and destruction within the flame zone. Note that axial diffusion is significant, so positions do not necessarily correlate with time as they do in a plug-flow reactor. However, the positions do correspond to a rising temperature, reaching a maximum temperature at $10 \mathrm{~mm}$ away from the burner surface, which is beyond the range of the graph in Fig. 10a.

Immediately, it is apparent that multiple reactions seem to be responsible for benzene formation. The model predicts a total of seven reactions that form benzene (shown as $\mathrm{C}_{6} \mathrm{H}_{6}$ ) and five reactions that consume it. By inspection, the highest formation rates are from 1,3-cyclohexadiene $\rightleftarrows \mathrm{C}_{6} \mathrm{H}_{6}+\mathrm{H}_{2}$, cyclohexadienyl $\left(c-\mathrm{C}_{6} \mathrm{H}_{7}\right) \rightleftarrows \mathrm{C}_{6} \mathrm{H}_{6}+\mathrm{H}$, and fulvene $+\mathrm{H} \rightleftarrows \mathrm{C}_{6} \mathrm{H}_{6}+\mathrm{H}$. The $\mathrm{C}_{3} \mathrm{H}_{3}+$ $\mathrm{C}_{3} \mathrm{H}_{3} \rightleftarrows \mathrm{C}_{6} \mathrm{H}_{6}$ reaction forms benzene at positions less than $4.5 \mathrm{~mm}$ away from the burner and destroys it at larger distances.

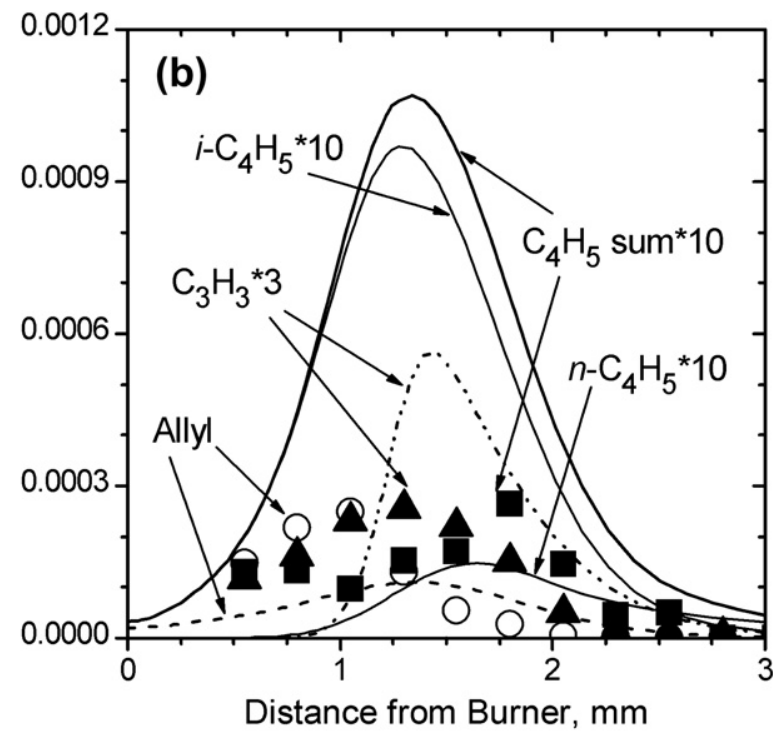

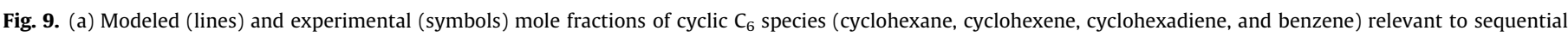

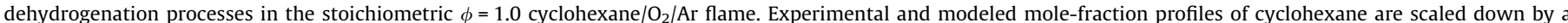

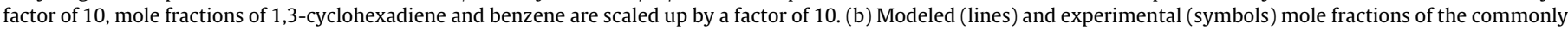
considered benzene precursors $\mathrm{C}_{3} \mathrm{H}_{3}$, allyl $\left(\mathrm{C}_{3} \mathrm{H}_{5}\right)$, and $\mathrm{C}_{4} \mathrm{H}_{5}$ (scaled up by 10 ). 

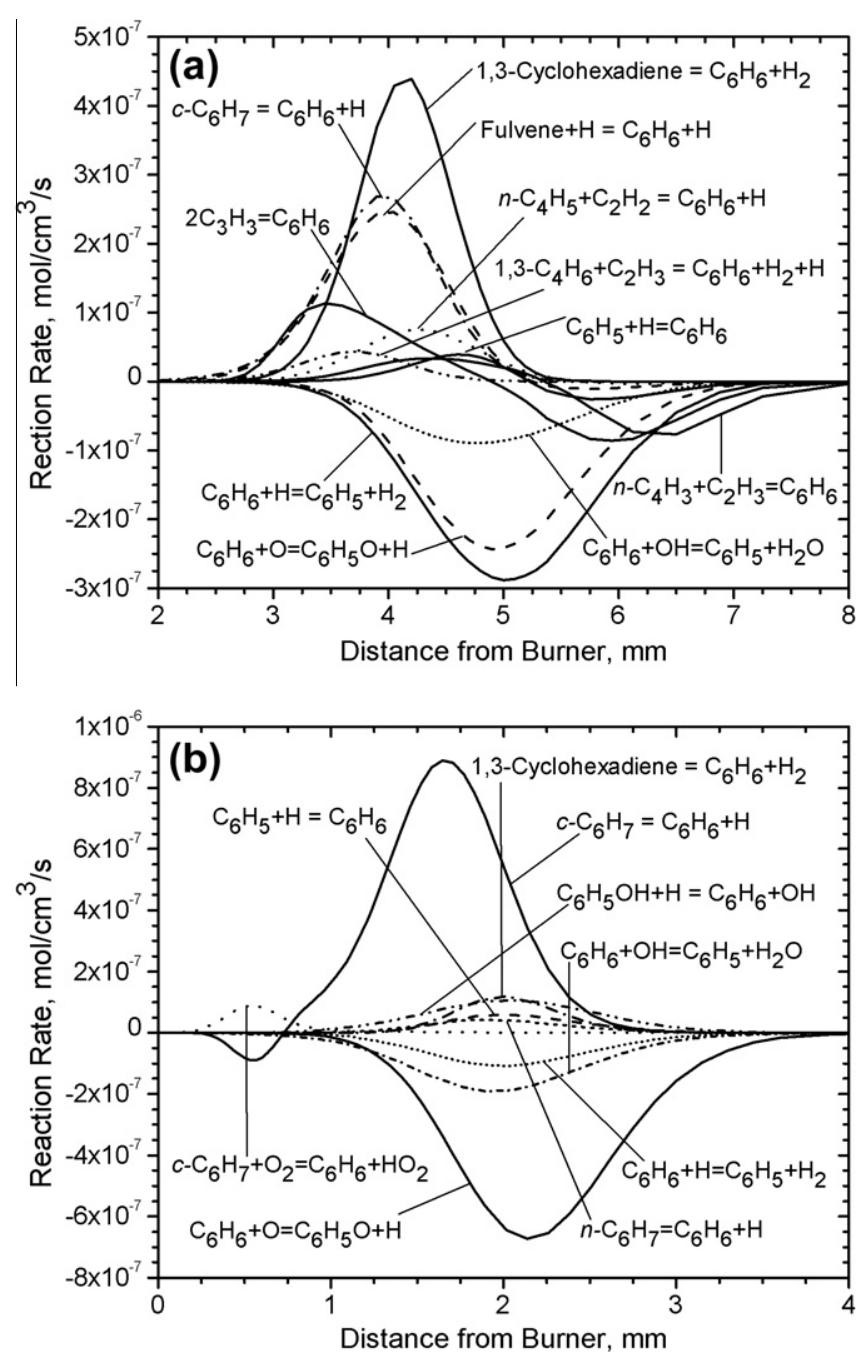

Fig. 10. Molar rates of production and consumption of benzene as computed from model predictions of cyclohexane $/ \mathrm{O}_{2} / \mathrm{Ar}$ flames: (a) fuel-rich, $\phi=2.0$, and (b) stoichiometric, $\phi=1.0$.

A complementary picture of reaction pathways comes by integrating each reaction rate in the set through the flame, obtaining their cumulative contributions to benzene formation. Using the predicted mole-fraction profiles and the model's rate constants, molar rates of benzene formation or consumption from each reaction can be calculated along the flow axis. Their integration provides the cumulative contribution.

For the fuel-rich flame, these results are shown in Fig. 11a. The thicknesses of the arrows in Fig. 11 are computed from the model predictions and are shown relative to the molar benzene formation rate from cyclohexadienyl in the stoichiometric flame (see below); the only exception is the open arrow in Fig. 11a that represents $i-$ $\mathrm{C}_{4} \mathrm{H}_{5}+\mathrm{H} \rightleftarrows \mathrm{C}_{3} \mathrm{H}_{3}+\mathrm{CH}_{3}$, whose reaction flux is too large to be shown (about 15 times that of cyclohexadienyl $\rightleftarrows \mathrm{C}_{6} \mathrm{H}_{6}+\mathrm{H}$ in stoichiometric flame). The benzene-pathway diagram for the fuel-rich flame, Fig. 11a, shows that 1,3-cyclohexadiene is the common origin of the two main benzene-formation pathways: $\mathrm{H}$-abstraction to form the cyclohexadienyl that decomposes to benzene $+\mathrm{H}$ (21\% of benzene formation) and direct decomposition to benzene $+\mathrm{H}_{2}$ (30\%). The rate coefficient used for "direct" decomposition of 1,3-cyclohexadiene is based on isomerization/ decomposition of 1,3-cyclohexadiene via a 1,4-cyclohexadiene structure, which decomposes to benzene over a lower barrier without forming a thermalized 1,4-cyclohexadiene intermediate [61].
$\mathrm{H}_{2}$ elimination from 1,4-cyclohexadiene itself, which is a loweractivation-energy process than from 1,3-cyclohexadiene, is not found to be important here because of the fuel-specific breakdown steps. In short, hydrogen is abstracted from cyclohexene preferentially at the allylic position, leading to a resonantly stabilized cyclohexenyl radical, which subsequently forms 1,3-cyclohexadiene. 1,4-Cyclohexadiene is not generated so easily, as it would have to be generated by $\mathrm{H}$-abstraction from the non-allylic position in cyclohexene. Thus, 1,4-cyclohexadiene is only formed in insignificant amounts.

As shown in Figs. 10a and 11a, the next most important reaction contributing to benzene formation is the fulvene $+\mathrm{H}$ reaction, which produces $21 \%$ of the benzene according to the model. Analysis shows that fulvene is formed mostly by $i-\mathrm{C}_{4} \mathrm{H}_{5}+\mathrm{C}_{2} \mathrm{H}_{2} \rightleftarrows$ fulvene $+\mathrm{H}$ (resulting in 7\% of the benzene formation) and $\mathrm{C}_{3} \mathrm{H}_{3}+\mathrm{C}_{3} \mathrm{H}_{5} \rightleftarrows$ fulvene $+2 \mathrm{H}$ (6\%), with additional contributions from $n-\mathrm{C}_{4} \mathrm{H}_{5}+\mathrm{C}_{2} \mathrm{H}_{2} \rightleftarrows$ fulvene $+\mathrm{H}(3 \%)$, and $2 \mathrm{C}_{3} \mathrm{H}_{3} \rightleftarrows$ fulvene (3\%).

Thus, $\mathrm{C}_{3} \mathrm{H}_{3}$ makes benzene both directly and indirectly. The direct reaction $2 \mathrm{C}_{3} \mathrm{H}_{3} \rightleftarrows$ benzene is predicted to contribute $8 \%$ of benzene formation in the fuel-rich flame. Including the $\mathrm{C}_{3} \mathrm{H}_{3}$-based fulvene routes, $\mathrm{C}_{3} \mathrm{H}_{3}$ reactions represent a total of $11 \%$ of the benzene formation. Although it is considered in Fig. 10a, the phenyl $+\mathrm{H} \rightleftarrows$ benzene channel is not a source for benzene here, as virtually all of the phenyl is predicted instead to be produced by benzene oxidation via $\mathrm{H}$-abstractions.

A predicted contribution of $n-\mathrm{C}_{4} \mathrm{H}_{5}+\mathrm{C}_{2} \mathrm{H}_{2} \rightleftarrows$ benzene $+\mathrm{H}$ ( $6 \%$ of the total benzene formation in the fuel-rich flame) is small but could be significant. As pointed out earlier, non-resonantly stabilized radicals like $n-\mathrm{C}_{4} \mathrm{H}_{5}$ are normally not found to be of importance for benzene formation. However, two possible reasons for the greater apparent significance of $n-\mathrm{C}_{4} \mathrm{H}_{5}$ in the fuel-rich cyclohexane flame are that: (1) 1,3-butadiene is formed rapidly in the high-temperature reaction zone by fuel destruction and (2) there is a fuel-specific $n-\mathrm{C}_{4} \mathrm{H}_{5}$ formation path from fuel destruction. As in many flames, $n-\mathrm{C}_{4} \mathrm{H}_{5}$ is primarily formed by $\mathrm{H}$-abstraction from 1,3-butadiene, which actually favors $i-\mathrm{C}_{4} \mathrm{H}_{5}$ formation [55], or vinyl addition to acetylene. However, unlike a 1,3-butadiene-fueled flame where the butadiene is being destroyed throughout the flame or other flames where butadiene is a relatively minor intermediate, butadiene is being generated as a principal intermediate in just the region where $n-\mathrm{C}_{4} \mathrm{H}_{5}$ and $i-\mathrm{C}_{4} \mathrm{H}_{5}$ can participate most effectively in benzene formation. Also in the cyclohexane flame, the allylic cyclohexenyl radical can undergo a ring-opening and form a linear hexa-3,5-dienyl $\left(\mathrm{CH}_{2}=\mathrm{CH}-\mathrm{CH}=\mathrm{CH}-\mathrm{CH}_{2}-\mathrm{CH}_{2}{ }^{\circ}\right)$ radical, which can dissociate by $\beta$-scission into $n-\mathrm{C}_{4} \mathrm{H}_{5}+\mathrm{C}_{2} \mathrm{H}_{4}$. The predicted significance of $n-\mathrm{C}_{4} \mathrm{H}_{5}$ could be affected by uncertainty in the $\mathrm{H}$-assisted isomerization of $n-\mathrm{C}_{4} \mathrm{H}_{5}$ to form $i-\mathrm{C}_{4} \mathrm{H}_{5}$ or by other $n-\mathrm{C}_{4} \mathrm{H}_{5}$ consumption reactions, as already speculated in Ref. [55], in which a very similar model was used. The formation chemistry of the benzene precursors is discussed in more detail in Section 5.2.

Other reactions are predicted to contribute to benzene formation in small amounts. According to the modeling results, the reaction of $1,3-\mathrm{C}_{4} \mathrm{H}_{6}$ (1,3-butadiene) with $\mathrm{C}_{2} \mathrm{H}_{3}$ (vinyl) provides $3 \%$ of all benzene in this flame. The $n-\mathrm{C}_{4} \mathrm{H}_{3}+\mathrm{C}_{2} \mathrm{H}_{3}$ reaction also contributes $3 \%$ to the overall benzene formation. Although these reactions are indicated in Fig. 10a, they do not appear in Fig. 11a because of their small overall contribution to the observed benzene levels.

Benzene in this flame is mainly consumed by reactions with $\mathrm{H}$ and $\mathrm{OH}$ to form $\mathrm{C}_{6} \mathrm{H}_{5}$ (phenyl) and with $\mathrm{O}$ to form $\mathrm{C}_{6} \mathrm{H}_{5} \mathrm{O}$ (phenoxy), as shown in Figs. 10a and 11a. Some benzene and phenyl are converted to toluene. Phenyl, phenoxy, and toluene are then destroyed by other reactions, although at these rich conditions, significant amounts of phenyl and toluene react to form highermolecular-weight species.

Using the same, updated model as for the rich flame, an identical reaction-rate analysis is made for the stoichiometric cyclohexane 
(a) Fuel-Rich Flame

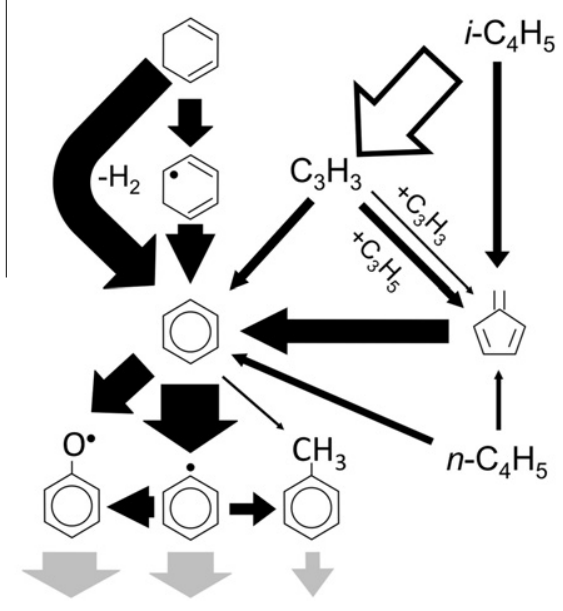

(b) Stoichiometric Flame

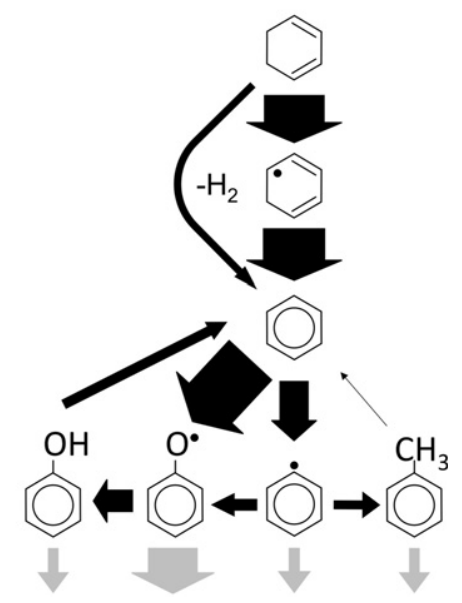

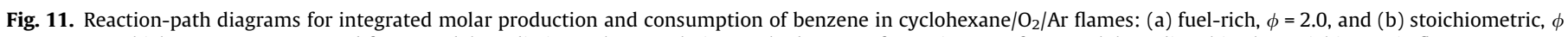
=1.0. Arrow thicknesses are computed from model predictions, shown relative to the benzene formation rate from cyclohexadienyl in the stoichiometric flame.

flame studied previously [8]. The conclusions, which do not differ significantly from the previous studies $[8,21]$, are summarized graphically in Figs. 10b and 11b. The modeling results indicate that only one reaction makes up most of the benzene formation: thermal decomposition of cyclohexadienyl forming $\mathrm{C}_{6} \mathrm{H}_{6}+\mathrm{H}$. Close to the burner surface, $c-\mathrm{C}_{6} \mathrm{H}_{7}$ also contributes via its oxidation reaction with $\mathrm{O}_{2}$. A total of $86 \%$ of the benzene formation is from cyclohexadienyl. Another $9 \%$ comes from $\mathrm{H}_{2}$ elimination from the dehydrogenation intermediate 1,3-cyclohexadiene. It would appear from Fig. 10 b that a small contribution arises from $\mathrm{C}_{6} \mathrm{H}_{5} \mathrm{OH}+\mathrm{H} \rightleftarrows-$ $\mathrm{C}_{6} \mathrm{H}_{6}+\mathrm{OH}$. However, this reaction is in effect a phenyl recycling step, diverting part of the phenoxy radical that represents the main phenyl destruction path as shown in Fig. 11b. A similar small recycle of phenyl comes through toluene $+\mathrm{H}$. As in the fuel-rich flame, benzene is oxidized by reactions with $\mathrm{H}, \mathrm{O}$, and $\mathrm{OH}$, forming phenyl and phenoxy. Finally, by comparing arrow thicknesses in Figs. 11a and b, the absolute benzene formation rate can be seen to be higher in the fuel-rich flame than in the stoichiometric flame.

In summary, the model identified that multiple routes to benzene co-exist in cyclohexane flames. In agreement with recent studies [8,21], the stepwise dehydrogenation with cyclohexadienyl decomposition as its final step is dominant at stoichiometric conditions. This particular benzene-formation route is joined in the fuel-rich flame by direct 1,3-cyclohexadiene decomposition and by small-radical chemistry including $i-\mathrm{C}_{4} \mathrm{H}_{5}, \mathrm{C}_{3} \mathrm{H}_{3}$, allyl, and possibly $n-\mathrm{C}_{4} \mathrm{H}_{5}$.

\subsection{Pathways of fuel consumption and benzene precursor formation}

For both the fuel-rich and the stoichiometric cyclohexane flames, the predicted fuel consumption and benzene precursor formation paths are discussed here using Fig. 12. In this figure, the thickness of the solid arrows is proportional to the reaction's integrated rate of molar flux, relative to the conversion rate of cyclohexane in the stoichiometric flame. Low integrated rates are shown as dashed lines if they are still $5 \%$ of the cyclohexane conversion rate.

As indicated in Fig. 12, in both the stoichiometric and the fuelrich flames, fuel consumption is mainly initiated by an $\mathrm{H}$-abstraction step forming cyclohexyl from cyclohexane. In the fuel-rich flame, a small amount of cyclohexane isomerizes to 1-hexene, which dissociates to make allyl and $n$-propyl [17]. Allyl radicals undergo further dehydrogenation processes and can eventually lead to $\mathrm{C}_{3} \mathrm{H}_{3}$ via $\mathrm{C}_{3} \mathrm{H}_{4}$ (allene and propyne), as indicated in Fig. 12a.
In both cyclohexane flames, most of the cyclohexyl $\beta$-scissions to form hex-5-enyl ( $\mathrm{CH}_{2}-\mathrm{CH}_{2}-\mathrm{CH}_{2}-\mathrm{CH}_{2}-\mathrm{CH}=\mathrm{CH}_{2}$ ). The fate of this linear radical is slightly different in the two flames. Decomposition to $\mathrm{C}_{2} \mathrm{H}_{4}$ + but-3-enyl ( $\mathrm{CH}_{2}-\mathrm{CH}_{2}-\mathrm{CH}=\mathrm{CH}_{2}$ ) and isomerization to the allylic hex-1-en-3-yl $\left(\mathrm{CH}_{2}=\mathrm{CH}-\mathrm{CH}-\mathrm{CH}_{2}-\mathrm{CH}_{2}-\mathrm{CH}_{3}\right)$ are equally contributing in the fuel-rich flame. In the stoichiometric flame, isomerization is more important than decomposition. In both flames, the allylic hex-1-en-3-yl $\left(\mathrm{CH}_{2}=\mathrm{CH}-\mathrm{CH}-\mathrm{CH}_{2}-\mathrm{CH}_{2}-\mathrm{CH}_{3}\right)$ undergoes a $\beta$-scission to 1,3-butadiene $+\mathrm{C}_{2} \mathrm{H}_{5}$ (ethyl). Conversion of but-3-enyl ( $\left.\mathrm{CH}_{2}-\mathrm{CH}_{2}-\mathrm{CH}=\mathrm{CH}_{2}\right)$ to 1,3-butadiene is more important in the fuel-rich flame, thus largely re-balancing the two $\mathrm{C}_{4}$ routes. Although not shown in Fig. 12, in subsequent steps, but3-enyl ( $\left.\mathrm{CH}_{2}-\mathrm{CH}_{2}-\mathrm{CH}=\mathrm{CH}_{2}\right)$ and 1,3-butadiene both make $\mathrm{C}_{2} \mathrm{H}_{4}+\mathrm{C}_{2} \mathrm{H}_{3}$, the first by $\beta$-scission and the second by chemically activated $\mathrm{H}$ addition. In both flames, $\mathrm{C}_{4} \mathrm{H}_{5}$ isomer radicals $\left(n-\mathrm{C}_{4} \mathrm{H}_{5}\right.$, $\mathrm{CH}_{2}=\mathrm{CH}-\mathrm{CH}=\mathrm{CH} \cdot$ and $i-\mathrm{C}_{4} \mathrm{H}_{5}, \mathrm{CH}_{2}=\mathrm{CH}-{ }^{\cdot} \mathrm{CH}=\mathrm{CH}_{2}$ ) are largely produced by $\mathrm{H}$-abstraction reactions from 1,3-butadiene. In the fuelrich flame, contributions towards $n-\mathrm{C}_{4} \mathrm{H}_{5}$ also arise from $\beta$-scission of the $\mathrm{CH}_{2}=\mathrm{CH}-\mathrm{CH}=\mathrm{CH}-\mathrm{CH}_{2}-\mathrm{CH}_{2} \cdot$ radical, as discussed above. This process, which is initiated by stepwise dehydrogenation of cyclohexane and ring-opening of the cyclohexenyl radical is indicated on the left side of Fig. 12a. The $n-\mathrm{C}_{4} \mathrm{H}_{5}$ isomers largely undergo $\mathrm{H}$-assisted isomerization to form $i-\mathrm{C}_{4} \mathrm{H}_{5}$, and eventually the $\mathrm{H}+i$ $\mathrm{C}_{4} \mathrm{H}_{5}$ reaction leads to $\mathrm{C}_{3} \mathrm{H}_{3}+\mathrm{CH}_{3}$.

Although the diagrams in Fig. 12 focus only on the pyrolysis mechanisms leading toward benzene precursors, the oxidation steps and the differing radical pools in both flames subtly influence the mixture of benzene-formation paths. In the fuel-rich flame, $\mathrm{H}$ atom is the dominant radical species, and the concentration of $\mathrm{OH}$ is an order of magnitude lower (Fig. 2). $\mathrm{H}$ and $\mathrm{OH}$ mainly abstract $\mathrm{H}$-atoms, but $\mathrm{H}$ and sometimes $\mathrm{OH}$ may as well combine with hydrocarbons to fragment them by chemically activated routes; $\mathrm{H}+1$,3-butadiene $\rightleftarrows \mathrm{C}_{2} \mathrm{H}_{3}+\mathrm{C}_{2} \mathrm{H}_{4}$ is an example. The higher $\mathrm{O}$ atom mole fraction in the stoichiometric flame, relative to the fuel-rich flame, is the key to oxidizing $\pi$-bonds of alkenes and aromatics. The low O-atom mole fraction at the fuel-rich condition hinders such oxidation reactions and allows $\pi$-bonded species to participate in molecular-weight-growth reactions. Oxidation steps also compete in consuming the major molecular and radical intermediates, including $\mathrm{CH}_{3}, \mathrm{C}_{2} \mathrm{H}_{2}, \mathrm{C}_{2} \mathrm{H}_{3}, \mathrm{C}_{2} \mathrm{H}_{4}$, and 1,3-butadiene. For example, in the fuel-rich flame, one-third of $\mathrm{C}_{2} \mathrm{H}_{3}$ is destroyed by $\mathrm{O}_{2}$. The competition between pyrolysis and oxidation steps affects the formation of benzene precursors. The modeling results predict that allyl radicals, which are commonly considered benzene 


\section{(a) Fuel-Rich Flame}

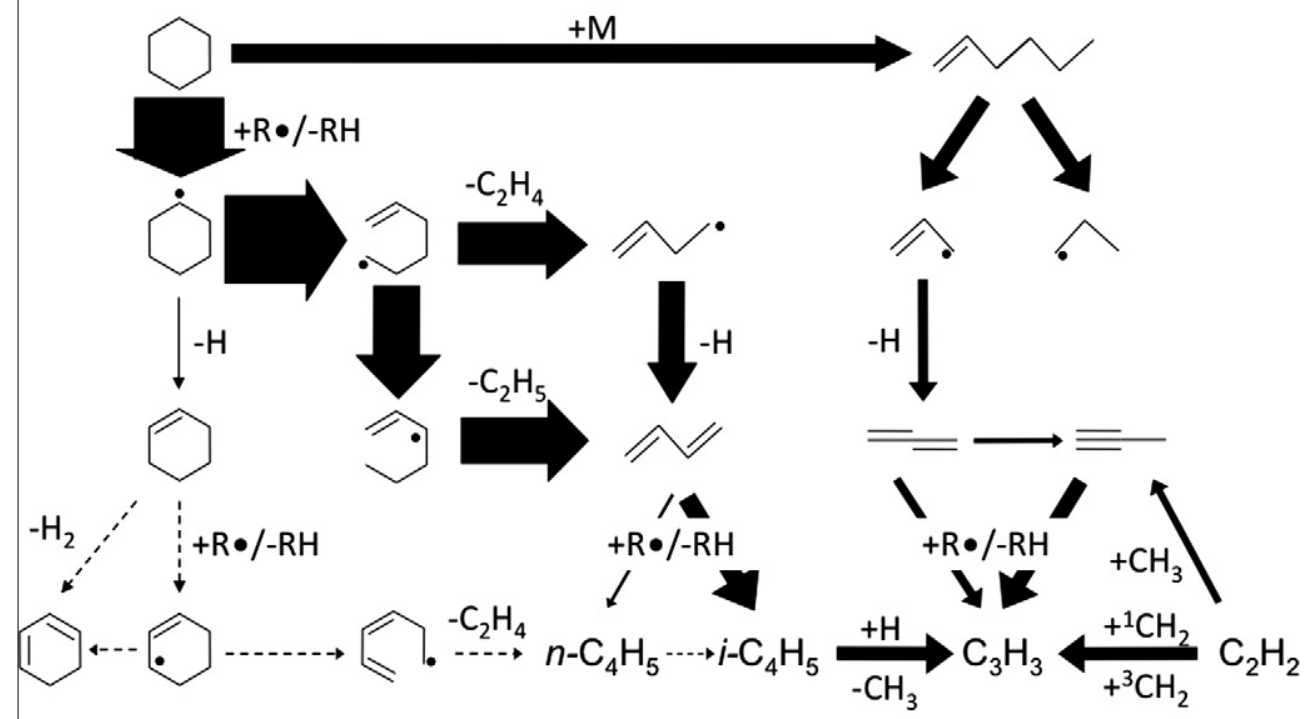

(b) Stoichiometric Flame

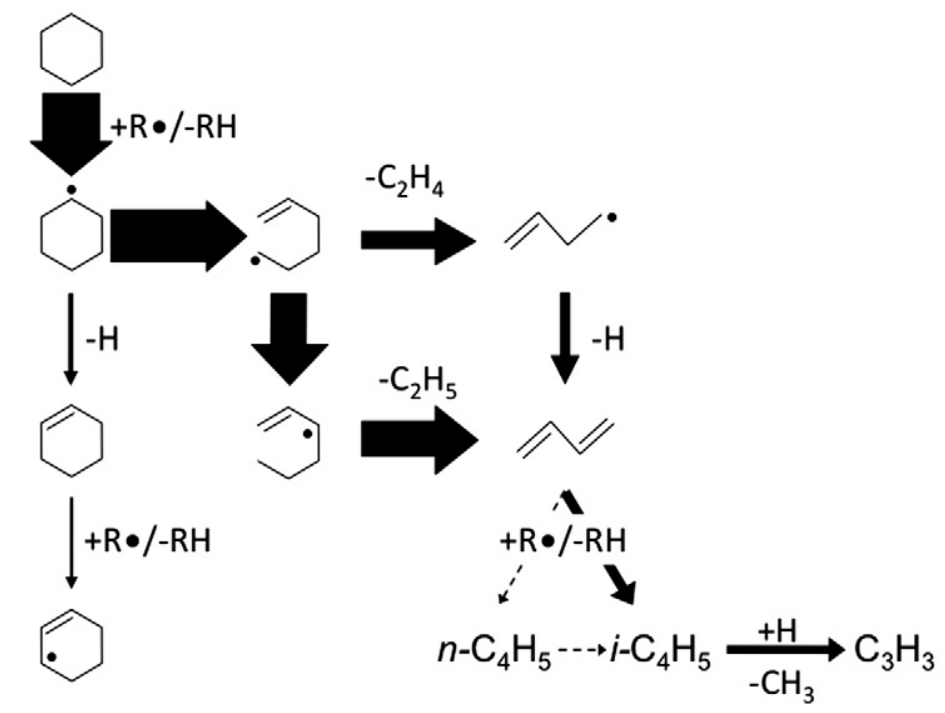

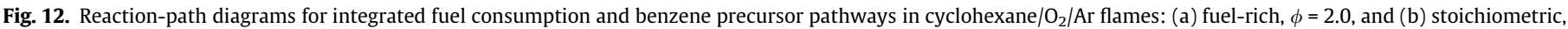

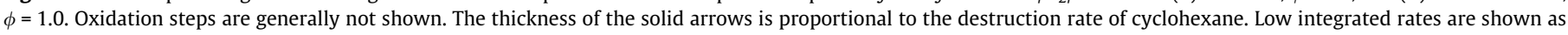
dashed lines if they are significant but less than $5 \%$ of the overall rate.

precursors, are mostly formed by oxidation through but-3-enyl + $\mathrm{HO}_{2}$ and 1,3-butadiene $+\mathrm{OH}$ and $\mathrm{O}$. Furthermore, a small amount of oxygen can promote benzene formation, by formation of $\mathrm{C}_{3} \mathrm{H}_{3}$ in the fuel-rich flame through reaction of $\mathrm{C}_{2} \mathrm{H}_{2}+{ }^{1} \mathrm{CH}_{2}$, where singlet $\mathrm{CH}_{2}$ is produced by $\mathrm{C}_{2} \mathrm{H}_{2}+\mathrm{O}$. As illustrated in Fig. 12a, the largest source of $\mathrm{C}_{3} \mathrm{H}_{3}$ in this flame $(27 \%)$ is $\mathrm{C}_{2} \mathrm{H}_{2}+$ singlet and triplet $\mathrm{CH}_{2}$, but next (21\%) is $i-\mathrm{C}_{4} \mathrm{H}_{5}+\mathrm{H} \rightleftarrows \mathrm{C}_{3} \mathrm{H}_{3}+\mathrm{CH}_{3}$, so part of the $\mathrm{C}_{3} \mathrm{H}_{3}$ contribution to benzene must be attributed to $i-\mathrm{C}_{4} \mathrm{H}_{5}$.

\subsection{Sensitivity to details of the small-hydrocarbon chemistry and the temperature profile}

Despite generally good agreement between the prediction and experiment, it is reasonable to question whether the mechanistic conclusions discussed above stem from the particular model and whether the products and pathway differences are due to temperature instead of stoichiometry effect. These ques- tions are answered by two types of simulations: (1) examining effects of differences in small-molecule kinetics by replacing the non- $\mathrm{C}_{6} \mathrm{H}_{x}$ reactions with the reaction set of Miller from Ref. [55] and (2) examining the effects of temperature-profile uncertainties by switching the temperature profiles to use the fuel-rich temperature profile for the stoichiometric flame and vice versa. The key findings of these tested simulations are discussed below.

First, using the correct temperature profiles with the Miller model [55] gives predictions in good agreement with the present model about the pathways important for fuel consumption and benzene formation, both at $\phi=1.0$ and 2.0. In the stoichiometric flame, benzene is dominantly produced from the gradual dehydrogenation of cyclo- $\mathrm{C}_{6}$ species; while in the fuel-rich flame, benzene is produced from the mix of stepwise dehydrogenation and smallradical-based growth chemistry. The same roles of $i-\mathrm{C}_{4} \mathrm{H}_{5}, \mathrm{C}_{3} \mathrm{H}_{3}$, allyl, and $n-\mathrm{C}_{4} \mathrm{H}_{5}$ are also borne out quantitatively. 
Second, the switched temperature profiles cause almost no change for the pathways of fuel consumption and benzene formation and the effects of stoichiometry. In the stoichiometric flame, cyclohexane still goes solely to cyclohexyl via H-abstractions, and in the fuel-rich flame a small amount goes through isomerization to 1-hexene. Additionally, benzene formation is still dominated by stepwise dehydrogenation in the stoichiometric flame, while for the fuel-rich flame, the same mix of benzene-formation pathways occurs as in the base modeling.

This analysis shows that the change toward multiple pathways to benzene in the fuel-rich flame is caused by the richness of the feed mixture. Lower concentration of $\mathrm{OH}$ radical at the fuel-rich condition makes $\mathrm{OH}+\mathrm{CO} \rightleftarrows \mathrm{H}+\mathrm{CO}_{2}$ and $\mathrm{OH}+\mathrm{H}_{2} \rightleftarrows \mathrm{H}+\mathrm{H}_{2} \mathrm{O}$ slower, causing slower heat release. Furthermore, the low concentrations of $\mathrm{O}$-atoms at the fuel-rich condition reduces the oxidation rate of species containing $\pi$-bonds. In combination, these effects cause greater standoff of the reaction zone from the burner. As shown in Fig. 10, the peak rate of benzene formation is $9.0 \times 10^{-7} \mathrm{~mol} / \mathrm{cm}^{3} / \mathrm{s}$ at $1.5 \mathrm{~mm}$ and about $1200 \mathrm{~K}$ for the stoichiometric flame and $4.5 \times 10^{-7} \mathrm{~mol} / \mathrm{cm}^{3} / \mathrm{s}$ at $3.8 \mathrm{~mm}$ and $1600 \mathrm{~K}$ for the fuel-rich flame. Thus, for the fuel-rich flame, benzene formation is delayed until higher temperatures, which causes the high-activation-energy decomposition of 1,3-cyclohexadiene to form benzene $+\mathrm{H}_{2}$ to be more important at $\phi=2.0$. In addition, at that point, mole fractions of $i-\mathrm{C}_{4} \mathrm{H}_{5}, \mathrm{C}_{3} \mathrm{H}_{3}$, allyl, and $n-\mathrm{C}_{4} \mathrm{H}_{5}$ are much higher as mentioned above, so their reactions contribute more to benzene formation under fuel-rich conditions.

\section{Conclusions}

Building on recent work by Hansen et al. [3] showing effects of fuel structure on the significance of different benzene-formation pathways, this research establishes the presence of multiple pathways to benzene in a fuel-rich, low-pressure cyclohexane flame, analyzed with VUV-photoionization molecular-beam mass spectrometry. A new reaction set for cyclohexane combustion gives good general agreement with the new data and with data from a previously studied stoichiometric cyclohexane flame [8]. Reaction path analysis shows that stepwise $\mathrm{H}$-abstraction and loss from cyclohexane represent the most important benzene-formation route in both flames. Under the stoichiometric conditions reinvestigated here, cyclohexadienyl $\left(c-\mathrm{C}_{6} \mathrm{H}_{7}\right)$ decomposition accounts for almost all benzene formed, while both cyclohexadienyl decomposition and the 1,3-cyclohexadiene $\rightleftarrows$ benzene $+\mathrm{H}_{2}$ reaction contribute at the fuel-rich condition. Additional reactions that become more important at the fuel-rich conditions are $i$ $\mathrm{C}_{4} \mathrm{H}_{5}+\mathrm{C}_{2} \mathrm{H}_{2}$ and $\mathrm{C}_{3} \mathrm{H}_{3}+$ allyl through fulvene and the $\mathrm{C}_{3} \mathrm{H}_{3}+\mathrm{C}_{3} \mathrm{H}_{3}$ reaction. The potential role of $n-\mathrm{C}_{4} \mathrm{H}_{5}$ through the reactions $n$ $\mathrm{C}_{4} \mathrm{H}_{5}+\mathrm{C}_{2} \mathrm{H}_{2} \rightleftarrows$ benzene/fulvene $+\mathrm{H}$ reaction is explained by cyclohexane-specific fuel effects.

The results presented here suggest that cycloalkane combustion and benzene formation may be modeled successfully through careful application of kinetics analogies from acyclic alkanes. In both cases, fuel consumption is generally initiated by $\mathrm{H}$-abstraction, as there are no $\pi$-bonds in alkanes and cycloalkanes. The resulting radicals then break the weakest bond, which normally is in $\beta$-position to the original radical site. Because of the higher bond energy of $\mathrm{C}-\mathrm{H}$ versus $\mathrm{C}-\mathrm{C}$ bonds, typically a $\mathrm{C}-\mathrm{C}$ bond breaks, although $\mathrm{C}-\mathrm{H} \beta$-scissions can also contribute. As small alkenes are generated, they can be oxidized, especially by O-atoms, in competition with further abstractions (facilitated by new, weaker allylic $\mathrm{C}-\mathrm{H}$ bonds) and further $\beta$-scissions.

In summary, the important benzene-formation differences for cycloalkanes vs. acyclic alkanes are fuel-dependent differences in kinetics. The principal alkyl decomposition routes for acyclic al- kanes and cycloalkanes lead to small-radical benzene precursors like $\mathrm{C}_{3} \mathrm{H}_{3}$, allyl, and $n-\mid i-\mathrm{C}_{4} \mathrm{H}_{5}$ isomers, providing pathways to benzene. However, for cycloalkanes, the secondary route of $\mathrm{C}-\mathrm{H}$ $\beta$-scission maintains a cyclic structure that does not have to be rebuilt. Furthermore, the resulting cycloalkene has four allylic hydrogens that may be abstracted easily, and the ring-dehydrogenation steps can continue, to 1,3-cyclohexadiene and benzene in the case of cyclohexane. An additional cyclo- $\mathrm{C}_{6}$-specific reaction is pericyclic elimination of $\mathrm{H}_{2}$ from cyclohexene and cyclohexadiene. Thus, in the fuel-rich cyclohexane flame, the dominant stepwise ring dehydrogenation routes proceed in parallel to small-molecule formation of aromatic rings.

\section{Acknowledgments}

We thank Paul Fugazzi and Sarah Ferrell for technical assistance and Juan Wang and Terrill A. Cool for their contributions in collecting the flame and cross-section data. We are also grateful to James A. Miller for sharing his reaction set, which we used to test our results. This work was supported by the Office of Basic Energy Sciences (BES), U.S. Department of Energy (USDOE), under DE-FG0291ER14192 (PRW) and by the DFG under KO 1363/18-3 (KKH). Sandia is a multi-program laboratory operated by Sandia Corporation for NNSA under contract DE-AC04-94-AL85000. The Advanced Light Source is supported by USDOE/BES under DE-ACO205CH11231. This work was partially supported by the National Center for Supercomputing Applications under grant number TGCTS090056 and used the Cobalt supercomputer.

\section{Appendix A. Supplementary material}

Supplementary data associated with this article can be found, in the online version, at doi:10.1016/j.combustflame.2011.03.014.

\section{References}

[1] H. Wang, Proc. Combust. Inst. 33 (2010) 41-67.

[2] H. Bockhorn, A. D'Anna, A.F. Sarofim, H. Wang (Eds.), Combustion Generated Fine Carbonaceous Particles, KIT Scientific Publishing, 2010.

[3] N. Hansen, T. Kasper, B. Yang, T.A. Cool, W. Li, P.R. Westmoreland, P. Oßwald, K. Kohse-Höinghaus, Proc. Combust. Inst. 33 (2010) 585-592.

[4] S. Ritter, Chem. Eng. News 83 (8) (2005) 37.

[5] P. Dagaut, Phys. Chem. Chem. Phys. 4 (2002) 2079-2094.

[6] S. Humer, A. Frassoldati, S. Granata, T. Faravelli, E. Ranzi, R. Seiser, K. Seshadri, Proc. Combust. Inst. 31 (2007) 393-400.

[7] R. Bounaceur, P.-A. Glaude, R. Fournet, V. Warth, F. Battin-Leclerc, in: Proc. European Combustion Meeting, Vienna, Austria, 2009. <http://arxiv.org/abs/ 0904.2967v1>.

[8] M.E. Law, P.R. Westmoreland, T.A. Cool, J. Wang, N. Hansen, T. Kasper, Proc. Combust. Inst. 31 (2007) 565-573.

[9] D. Voisin, A. Marchal, M. Reuillon, J.-C. Boettner, M. Cathonnet, Combust. Sci. Technol. 138 (1998) 137-158.

[10] A. El Bakali, M. Braun-Unkhoff, P. Dagaut, P. Frank, M. Cathonnet, Proc Combust. Inst. 38 (2000) 1631-1638.

[11] S.G. Davis, C.K. Law, Combust. Sci. Technol. 140 (1998) 427-449.

[12] O. Lemaire, M. Ribaucour, M. Carlier, R. Minetti, Combust. Flame 127 (2001) 1971-1980.

[13] C.S. McEnally, L.D. Pfefferle, Proc. Combust. Inst. 30 (2005) 1425-1432.

[14] C.S. McEnally, L.D. Pfefferle, Combust. Flame 136 (2004) 155-167.

[15] W. Tsang, Int. J. Chem. Kinet. 10 (1978) 1119-1138.

[16] B. Sirjean, F. Buda, H. Hakka, P.A. Glaude, R. Fournet, V. Warth, F. Battin-Leclerc M. Ruiz-Lopez, Proc. Combust. Inst. 31 (2007) 277-284.

[17] J.H. Kiefer, K.S. Gupte, L.B. Harding, S.J. Klippenstein, J. Phys. Chem. A 113 (2009) 13570-13583.

[18] P.J. Bennett, D. Gregory, R.A. Jackson, Combust. Sci. Technol. 115 (1996) 83103.

[19] T.C. Brown, K.D. King, T.T. Nguyen, J. Phys. Chem. 90 (1986) 419-424.

[20] S.E. Klai, F.J. Baronnet, J. Chim. Phys. 90 (1993) 1951-1998.

[21] H.R. Zhang, L.K. Huynh, N. Kungwan, Z. Yang, S. Zhang, J. Phys. Chem. A 111 (2007) 4102-4115.

[22] S. Granata, T. Faravelli, E. Ranzi, Combust. Flame 132 (2003) 533-544.

[23] E. Ranzi, M. Dente, A. Goldaniga, G. Bozzano, T. Faravelli, Prog. Energy Combust. Sci. 27 (2001) 99-139.

[24] F. Buda, B. Heyberger, R. Fournet, P.A. Glaude, V. Warth, F. Battin-Leclerc, Energy Fuel 20 (2006) 1450-1459. 
[25] E.J. Silke, W.J. Pitz, C.K. Westbrook, M. Ribaucour, J. Phys. Chem. A 111 (2007) 3761-3775.

[26] C.S. McEnally, L.D. Pfefferle, B. Atakan, K. Kohse-Höinghaus, Prog. Energy Combust. Sci. 32 (2006) 247-294.

[27] A.P. Zeelenberg, H.W. Bruijn, Combust. Flame 9 (1965) 281-295

[28] M. Ribaucour, O. Limaire, R. Minetti, Proc. Combust. Inst. 29 (2002) $1303-$ 1310.

[29] G. Dayma, P.A. Glaude, R. Fournet, F. Battin-Leclerc, Int. J. Chem. Kinet. 35 (2003) 273-285.

[30] T.A. Cool, K. Nakajima, T.A. Mostefaoui, F. Qi, A. McIlroy, P.R. Westmoreland, M.E. Law, L. Poisson, D.S. Peterka, M. Ahmed, J. Chem. Phys. 119 (2003) 83568365.

[31] T.A. Cool, A. Mcllroy, P.R. Westmoreland, M. Ahmed, D.S. Peterka, L. Poisson, Rev. Sci. Instrum. 76 (2005) 094102-1-094102-7.

[32] T.A. Cool, K. Nakajima, C.A. Taatjes, A. Mcllroy, P.R. Westmoreland, M.E. Law, A. Morel, Proc. Combust. Inst. 30 (2005) 1681-1688.

[33] C.A. Taatjes, N. Hansen, D.L. Osborn, K. Kohse-Höinghaus, T.A. Cool, P.R. Westmoreland, Phys. Chem. Chem. Phys. 10 (2008) 20-34.

[34] N. Hansen, T.A. Cool, P.R. Westmoreland, K. Kohse-Höinghaus, Prog. Energy Combust. Sci. 35 (2009) 168-191.

[35] P. Osswald, U. Struckmeier, T. Kasper, K. Kohse-Höinghaus, J. Wang, T.A. Cool, N. Hansen, P.R. Westmoreland, J. Phys. Chem. A 111 (2007) 4093-4101.

[36] H. Koizumi, J. Chem. Phys. 95 (1991) 5846-5852.

[37] J.C. Biordi, Prog. Energy Combust. Sci. 3 (3) (1977) 151-173.

[38] C.A. Taatjes, D.L. Osborn, T.M. Selby, G. Meloni, J. Phys. Chem. A 112 (2008) 9336-9343.

[39] J.A.R. Samson, G.N. Haddad, T. Masuoka, P.N. Pareek, D.A.L. Kilcoyne, J. Chem. Phys. 90 (1989) 6925-6932.

[40] T.A. Cool, J. Wang, K. Nakajima, C.A. Taatjes, A. McIlroy, Int. J. Mass Spectrom. 247 (2005) 18-27.

[41] T. Schuessler, W. Roth, T. Gerber, C. Alcraraz, I. Fischer, Phys. Chem. Chem. Phys. 7 (2005) 819-825.

[42] J. Wang, B. Yang, T.A. Cool, N. Hansen, T. Kasper, Int. J. Mass Spectrom. 269 (2008) 210-220.

[43] G. Cooper, J.E. Anderson, C.E. Brion, Chem. Phys. 209 (1996) 61-77.

[44] J.C. Robinson, N.E. Sveum, D.M. Neumark, J. Chem. Phys. 119 (2003) 53115314.

[45] J.C. Robinson, N.E. Sveum, D.M. Neumark, Chem. Phys. Lett. 383 (2004) 601605.

[46] Z. Zhou, M. Xie, Z. Wang, F. Qi, Rapid Commun. Mass Spectrom. 23 (2009) 3994-4002.

[47] J.C. Biordi, C.P. Lazzara, J.F. Papp, Combust. Flame 23 (1974) 73-82.

[48] U. Struckmeier, P. Oßwald, T. Kasper, L. Böhling, M. Heusing, M. Köhler, A. Brockhinke, K. Kohse-Höinghaus, Z. Phys. Chem. 223 (2009) 503-537.

[49] N. Hansen, J.A. Miller, P.R. Westmoreland, T. Kasper, K. Kohse-Höinghaus, J. Wang, T.A. Cool, Combust. Flame 156 (2009) 2153-2164.

[50] A.M. Dean, J. Phys. Chem. 89 (21) (1985) 4600-4608.

[51] P.R. Westmoreland, J.B. Howard, J.P. Longwell, A.M. Dean, AIChE J. 32 (1986) 1971-1979.
[52] J.A. Miller, S.J. Klippenstein, J. Phys. Chem. A 107 (2003) 2680-2692

[53] L.B. Harding, S.J. Klippenstein, Y. Georgievskii, J. Phys. Chem. A 111 (2007) 3789-3801.

[54] J.A. Miller, S.J. Klippenstein, J. Phys. Chem. A 107 (2003) 7783-7799.

[55] N. Hansen, J.A. Miller, T. Kasper, K. Kohse-Höinghaus, P.R. Westmoreland, J. Wang, T.A. Cool, Proc. Combust. Inst. 32 (2009) 623-630.

[56] S.J. Klippenstein, J.A. Miller, J. Phys. Chem. A 109 (2005) 4285-4295.

[57] R.P. Duran, V.T. Amorebieta, A.J. Colussi, J. Phys. Chem. 92 (1988) 636-640.

[58] K.M. Leung, R.P. Lindstedt, Combust. Flame 102 (1995) 129-160.

[59] J.P. Senosiain, J.A. Miller, J. Phys. Chem. A 111 (2007) 3740-3747.

[60] Y. Georgievskii, J.A. Miller, S.J. Klippenstein, Phys. Chem. Chem. Phys. 9 (2007) 4259-4268.

[61] R.A. Shandross, J.B. Howard, J.P. Longwell, Proc. Combust. Inst. 26 (1996) 711719.

[62] M. Yahyaoui, N. Djebaïli-Chaumeix, P. Dagaut, C.-E. Paillard, S. Gail, Combust. Flame 147 (2006) 67-78.

[63] R.J. Kee, J.A. Miller, T.H. Jefferson, CHEMKIN II version 2.5: A General-Purpose, Problem-Independent, Transportable, Fortran Chemical Kinetics Code Package, SAND80-8003, Sandia National Laboratories, Livermore, California, 1980. Modification of CHEMKIN version 3.9, 1992.

[64] R.J. Kee, G. Dixon-Lewis, J. Warnatz, M.E. Coltrin, J.A. Miller, A Fortran Computer Package for the Evaluation of Gas-Phase, Multicomponent Transport Properties, SAND87-8246, Sandia National Laboratories, Livermore, California, 1986. Modification of TRANLIB version 1.6, 1990.

[65] R.J. Kee, J.F. Grcar, M.D. Smooke, J.A. Miller, A Fortran Program for Modeling Steady Laminar One-Dimensional Premixed Flames, SAND85-8240, Sandia National Laboratories, Livermore, California, 1985. Modification of PREMIX version 2.5, 1991.

[66] D.R.F. Burgess, Program XSenkplot, National Institute of Standards and Technology, 1997.

[67] S. Dooley, F.L. Dryer, B. Yang, J. Wang, T.A. Cool, T. Kasper, N. Hansen, Combust. Flame 158 (2011) 732-741.

[68] J.A. Miller, M.J. Pilling, J. Troe, Proc. Combust. Inst. 30 (2005) 43-88.

[69] J.A. Miller, C.F. Melius, Combust. Flame 91 (1992) 21-39.

[70] P.R. Westmoreland, A.M. Dean, J.B. Howard, J.P. Longwell, J. Phys. Chem. 93 (1989) 8171-8180.

[71] N. Hansen, S.J. Klippenstein, C.A. Taatjes, J.A. Miller, J. Wang, T.A. Cool, B. Yang, R. Yang, L. Wei, C. Huang, J. Wang, F. Qi, M.E. Law, P.R. Westmoreland, T. Kasper, K. Kohse-Höinghaus, J. Phys. Chem. A 110 (2006) 3670-3678.

[72] K. Kohse-Höinghaus, B. Atakan, A. Lamprecht, G. Gonzalez Alatorre, M. Kamphus, T. Kasper, N.-N. Liu, Phys. Chem. Chem. Phys. 4 (2002) 2056-2062.

[73] L.V. Moskaleva, A.M. Mebel, M.C. Lin, Proc. Combust. Inst. 26 (1996) 521-526.

[74] A. Lifshitz, C. Tamburu, A. Suslensky, F. Dubnikova, Proc. Combust. Inst. 30 (2005) 1039-1047.

[75] R.G. Butler, I. Glassman, Proc. Combust. Inst. 32 (2009) 395-402.

[76] N. Hansen, W. Li, M.E. Law, T. Kasper, P.R. Westmoreland, B. Yang, T.A. Cool, A. Lucassen, Phys. Chem. Chem. Phys. 12 (2010) 12112-12122. 